\title{
Evidence for a three-phase sequence during Heinrich Stadial 4 using a multiproxy approach based on Greenland ice core records
}

\author{
M. Guillevic ${ }^{1,2}$, L. Bazin 1 , A. Landais ${ }^{1}$, C. Stowasser ${ }^{2}$, V. Masson-Delmotte ${ }^{1}$, T. Blunier ${ }^{2}$, F. Eynaud ${ }^{3}$, S. Falourd ${ }^{1}$, \\ E. Michel ${ }^{1}$, B. Minster ${ }^{1}$, T. Popp ${ }^{2}$, F. Prié ${ }^{1}$, and B. M. Vinther ${ }^{2}$ \\ ${ }^{1}$ Laboratoire des Sciences du Climat et de l'environnement, UMR CEA/CNRS/UVSQ 8212, Gif-sur-Yvette, France \\ ${ }^{2}$ Centre for Ice and Climate, Niels Bohr Institute, University of Copenhagen, Copenhagen, Denmark \\ ${ }^{3}$ Laboratoire EPOC, UMR CNRS 5805 EPOC-OASU, Université Bordeaux 1, Talence, France \\ Correspondence to: M. Guillevic (mgllvc@nbi.ku.dk)
}

Received: 28 February 2014 - Published in Clim. Past Discuss.: 27 March 2014

Revised: 15 October 2014 - Accepted: 3 November 2014 - Published: 2 December 2014

\begin{abstract}
Glacial climate was characterised by two types of abrupt events. Greenland ice cores record DansgaardOeschger events, marked by abrupt warming in-between cold, stadial phases. Six of these stadials appear related to major Heinrich events (HEs), identified from ice-rafted debris (IRD) and large excursions in carbon- and oxygen-stable isotopic ratios in North Atlantic deep sea sediments, documenting major ice sheet collapse events. This finding has led to the paradigm that glacial cold events are induced by the response of the Atlantic Meridional Overturning Circulation to such massive freshwater inputs, supported by sensitivity studies conducted with climate models of various complexities. These models also simulate synchronous Greenland temperature and lower-latitude hydrological changes.

To investigate the sequence of events between climate changes at low latitudes and in Greenland, we provide here the first ${ }^{17} \mathrm{O}$-excess record from a Greenland ice core during Dansgaard-Oeschger events 7 to 13, encompassing H4 and H5. Combined with other ice core proxy records, our new ${ }^{17} \mathrm{O}$-excess data set demonstrates that stadials are generally characterised by low ${ }^{17} \mathrm{O}$-excess levels compared to interstadials. This can be interpreted as synchronous change of high-latitude temperature and lower-latitude hydrological cycle (relative humidity at the oceanic source of evaporation or change in the water mass trajectory/recharge) and/or an influence of local temperature on ${ }^{17} \mathrm{O}$-excess through kinetic effect at snow formation. As an exception from this general pattern, stadial 9 consists of three phases, characterised first by Greenland cooling during $550 \pm 60$ years (as shown by markers of Greenland temperature $\delta^{18} \mathrm{O}$ and $\delta^{15} \mathrm{~N}$ ), fol-
\end{abstract}

lowed by a specific lower-latitude fingerprint as identified from several proxy records (abrupt decrease in ${ }^{17} \mathrm{O}$-excess, increase in $\mathrm{CO}_{2}$ and methane mixing ratio, heavier $\delta \mathrm{D}-\mathrm{CH}_{4}$ and $\delta^{18} \mathrm{O}_{\mathrm{atm}}$ ), lasting $740 \pm 60$ years, itself ending approximately $390 \pm 50$ years prior to abrupt Greenland warming. We hypothesise that this lower-latitude signal may be the fingerprint of Heinrich event 4 in Greenland ice cores. The proposed decoupling between stable cold Greenland temperature and low-latitude climate variability identified for stadial 9 provides new targets for benchmarking climate model simulations and testing mechanisms associated with millennial variability.

\section{Introduction}

Glacial climate is characterised by millennial variability, recorded with specific expressions in different archives and at different latitudes (Voelker, 2002; Clement and Peterson, 2008). Greenland ice core records of ice $\delta^{18} \mathrm{O}$, a qualitative proxy of air temperature, unveiled at high resolution the succession of cold phases (Greenland Stadials, GS) and warm phases (Greenland Interstadials, GI) forming the 25 Dansgaard-Oeschger events (DO) of the last glacial period (NGRIP members, 2004). DO events are recorded through climatic and environmental changes in other North Atlantic/European archives such as speleothems (Genty et al., 2010; Boch et al., 2011), pollen and marine bioindicators from North Atlantic marine cores (e.g. Voelker, 2002; Sánchez Goñi and Harrison, 2010), with interstadials being 
characterised in Western Europe by warmer and more humid conditions, while stadials are associated with a dry and cold climate. The Tropics also exhibit a fingerprint of DO events as suggested e.g. by (i) variations in monsoon strength (e.g. recorded in speleothem growth rate and calcite $\delta^{18} \mathrm{O}$, Wang et al., 2001), (ii) changes in the atmospheric methane concentration (as measured in ice cores, Chappellaz et al., 1993, 2013) with its main source located at low latitudes during glacial periods (e.g. Baumgartner et al., 2012), or (iii) changes in the isotopic composition of atmospheric oxygen $\delta^{18} \mathrm{O}_{\mathrm{atm}}$ measured in air from ice cores (Landais et al., 2007; Severinghaus et al., 2009), reflecting at this timescale changes in the low-latitude water cycle and global biosphere productivity (Bender et al., 1994b). Such variations in the low-latitude climate are probably due to shifts in the Intertropical Convergence Zone (ITCZ, e.g. Peterson et al., 2000). The bipolar seesaw identified between each Greenland DO event and its Antarctic counterpart (EPICA community members, 2006; Capron et al., 2010) supports a key role of reorganisations of the Atlantic Ocean interhemispheric heat transport (Stocker and Johnsen, 2003), likely associated with strong variations of the Atlantic Meridional Overturning Circulation (AMOC) intensity.

In addition to palaeoclimate records showing this DO succession, a prominent feature identified in North Atlantic marine sediment cores is the occurrence of ice-rafted debris (IRD, Ruddiman, 1977). These IRD are interpreted as the signature of massive iceberg discharges in the North Atlantic Ocean originating from the Laurentide, Icelandic, BritishIrish and Fennoscandian ice sheets (e.g. Heinrich, 1988; Bond et al., 1993). Six such Heinrich events (HEs, numbered H1 to H6, Fig. 1) have been unambiguously identified during GS phases of the last glacial period (e.g. Bond et al., 1992; Hemming, 2004). Minor events identified in one or a few cores have additionally been reported - H5a (Rashid et al., 2003), H7a, H7b, H8 to H10 (Rasmussen et al., 2003), see Fig. 1. In addition to the IRD layers, periods of low surface salinity likely due to enhanced freshwater fluxes have been evidenced in a sediment core from the Celtic margin (Fig. 1 blue areas, Eynaud et al., 2012). Studies on the composition of each IRD layer have demonstrated the dominant Laurentide origin of $\mathrm{H} 2, \mathrm{H} 4$ and $\mathrm{H} 5$, while $\mathrm{H} 3$ and $\mathrm{H} 6$ are mainly due to icebergs delivery from European ice sheets (Grousset et al., 1993, 2000; Gwiazdaet al., 1996; Hemming et al., 1998; Snoeckx et al., 1999; Jullien et al., 2006). H1 results from the collapse of several ice sheets (Stanford et al., 2011).

The early proposed synchronicity of HEs in marine cores and GS in Greenland ice cores (e.g. Bond et al., 1993) has led to the paradigm that Greenland stadial/interstadial variability is related to freshwater-induced changes in AMOC. Indeed, the response of climate models of different complexities to freshwater perturbations bears similarities with palaeoclimate observations (e.g. Kageyama et al., 2013). Such GS associated to HEs are also called Heinrich stadials (Barker et al., 2009). Unfortunately, uncertainties associated with ma- rine and ice core chronologies have so far prevented the determination of the exact timing of Heinrich events with respect to GS (Sánchez Goñi and Harrison, 2010; Austin and Hibbert, 2012). In addition, several lines of evidence suggest that HEs are shorter than the corresponding GS (Peters et al., 2008; Roche et al., 2004) and occur after the AMOC entered a weakening trend (Flückiger et al., 2006; Marcott et al., 2011). Therefore the mechanisms relating iceberg discharge, low-latitude climate change and Greenland temperature change during stadials remain debated (Hemming, 2004; Clement and Peterson, 2008; Mulitza et al., 2008).

The impact of HEs is not limited to the North Atlantic but has a signature in mid- to low-latitude palaeoclimate records. For instance speleothem growth rate from South America and Asia and their calcite isotopes indicate a southward displacement of the intertropical convergence zone (ITCZ) during stadials compared to interstadials (e.g. Jo et al., 2014), most pronounced during Heinrich stadials (Kanner et al., 2012; Wang et al., 2007; Mosblech et al., 2012). Model simulations indeed produce in a few years a southward displacement of the ITCZ over the Atlantic Ocean and its margins in response to North Atlantic cooling (e.g. Chiang et al., 2008; Bozbiyik et al., 2011; Cvijanovic and Chiang, 2013). Speleothems from low latitudes have the advantage to provide the best absolute chronology amongst palaeo archives so far, through uranium-thorium dating of the calcite. Associated uncertainties can be as low as $\sim \pm 1 \%(2 \sigma)$ of the absolute age for the Hulu cave record (Wang et al., 2001). Calcite $\delta^{18} \mathrm{O}$ from Southeast Asia speleothems and $\delta^{18} \mathrm{O}_{\mathrm{atm}}$ variations registered in the air entrapped from ice cores are both mostly controlled by latitudinal shifts of the ITCZ and associated changes in the isotopic composition of tropical precipitation (e.g. Severinghaus et al., 2009). This common driving climatic mechanism therefore offers a direct link between speleothem and ice core archives. However, climateindependent markers have not yet been identified that would allow us to synchronise speleothems to other archives from different latitudes such as marine or ice cores, preventing a precise comparison of the timing of events between high, mid and low latitudes associated with Heinrich events.

In Greenland ice cores, DO events are well dated thanks to annual layer counting. For the GICC05 timescale used here, absolute ages are estimated with $\sim 3 \%$ uncertainty $(2 \sigma)$ during the glacial period (Svensson et al., 2008, and Appendix A1). A precise synchronisation between marine and ice cores during HEs remains however difficult to establish due to the lack of a direct HE fingerprint within the Greenland ice core records. Neither ice $\delta^{18} \mathrm{O}$ (a qualitative proxy of temperature) nor Greenland temperature (reconstructed from $\delta^{15} \mathrm{~N}$ measurements in the air bubbles based on firn gas gravitational and thermal fractionation) exhibit any additional cooling during Heinrich stadials compared to Greenland stadials (Figs. 1, 4a, b and e.g. Kindler et al., 2014). However, Greenland ice cores do provide proxy records influenced by high-, mid- and low-latitude climate changes. This archive 
should thus allow us to explore time leads and lags in between events happening at different latitudes.

The combination of all stable water isotopes has been proposed as a methodology to disentangle local from more remote effects recorded in ice cores (Vimeux et al., 1999; Stenni et al., 2001; Masson-Delmotte et al., 2005; Jouzel et al., 2007; Landais et al., 2012b). $\delta^{18} \mathrm{O}$ is a qualitative proxy of local Greenland temperature showing the well-known GS-GI pattern. Deuterium excess (d-excess $=\delta D-8 \delta^{18} \mathrm{O}$, Dansgaard, 1964) bears a signature of vapour source characteristics (sea surface temperature and relative humidity), but it is also affected by changes in condensation temperature (Masson-Delmotte et al., 2005; Jouzel et al., 2007; Steen-Larsen et al., 2013; Bonne et al., 2014). Temperature influences similarly the fractionation coefficients associated with $\delta^{17} \mathrm{O}$ and $\delta^{18} \mathrm{O}$ while the variations of fractionation coefficients associated with $\delta \mathrm{D}$ follow a different link with temperature (Barkan and Luz, 2005; Majoube, 1971; Luz et al., 2009). As a consequence, ${ }^{17} \mathrm{O}$-excess defined as $\ln \left(\delta^{17} \mathrm{O}+1\right)-0.528 \ln \left(\delta^{18} \mathrm{O}+1\right)$ is less sensitive than $\mathrm{d}$ excess to the distillation history, hence to local (Greenland) temperature (Masson-Delmotte et al., 2005; Landais et al., 2012b). ${ }^{17} \mathrm{O}$-excess therefore better reflects the climatic conditions during evaporation or moisture recharge of Greenland vapour source, in particular the relative humidity that controls kinetic fractionation during such processes. At NEEM, a simple water isotopic model tuned on seasonal data has enabled one to show that ${ }^{17} \mathrm{O}$-excess increases by 1 per meg for a $1 \%$ decrease in relative humidity of the source evaporative region (Landais et al., 2012b).

Still, because kinetic fractionation is also important during snow formation and as already observed for d-excess (Jouzel et al., 2007), the influence of condensation temperature on ${ }^{17} \mathrm{O}$-excess increases when temperature decreases. While this effect is of second order for Greenland sites or Antarctic sites with a $\delta^{18} \mathrm{O}$ level higher than $-40 \%$ (Winkler et al., 2012; Landais et al., 2012b), it is dominant for colder sites in Antarctica (Landais et al., 2012a; Schoenemann et al., 2014). This is the reason why ${ }^{17} \mathrm{O}$-excess and $\mathrm{d}$-excess need to be combined with other ice core proxies of the lower latitudes (e.g. $\delta^{18} \mathrm{O}_{2}$ of $\mathrm{O}_{2}, \mathrm{CH}_{4}$ ) to faithfully establish the relationship between climate and environmental changes in both polar and lower latitudes.

In this study, we investigate multiple climate proxies registered in the NEEM (North Greenland Eemian Ice Drilling) and NGRIP (North Greenland Ice Core Project) Greenland ice cores (Fig. 2), on the same chronology (Greenland Ice Core Chronology 2005 or GICC05, Appendix A), giving information about the local as well as the remote climate on exactly the same timescale. The aim is to test the synchronicity of climate events at high and low latitudes during Greenland stadials. With this purpose, we present the first ${ }^{17} \mathrm{O}$-excess record over a sequence of DO events, with a specific focus over GS-9 (following GI-9 and preceding GI-8 according to the INTIMATE labelling scheme that we use in this study
(Björck et al., 1998), 38 220-39900 years before 2000 AD (a b2k) on the GICC05 timescale). GS-9 is characterised by the occurrence of the major H4 IRD event of mostly Laurentide ice sheet (LIS) origin (Hemming, 2004; Jullien et al., 2006). This event occurs during Marine Isotope Stage 3 (MIS3), a period consisting of short-lived and frequent DO events (NGRIP members, 2004). In the following we will argue that the climatic fingerprint of $\mathrm{H} 4$ can be identified in multiple proxy records sensitive to climate and environmental changes at high, mid and low latitudes, archived in the ice and air of Greenland ice cores.

\section{Measurement method}

\section{$2.1 \quad{ }^{17}$ O-excess}

We have performed the first ${ }^{17} \mathrm{O}$-excess measurements on the NEEM ice core (Dahl-Jensen and NEEM community members, 2013, localisation on Fig. 2), spanning a sequence of 7 DO events during MIS 3, from GI-7 to GI-13. The method for ${ }^{17} \mathrm{O}$-excess measurements was first described in Luz and Barkan (2005). Two microlitres of water are fluorinated under a helium flow and the resulting oxygen $\mathrm{O}_{2}$ is purified on a molecular sieve before being trapped in a manifold immersed in liquid helium. $\mathrm{O}_{2}$ is then measured on a DELTA V isotope ratio mass spectrometer vs. pure oxygen. Dual inlet measurements last $75 \mathrm{~min}$ for each converted oxygen sample. Each water sample has been converted and measured at least twice. Every day, we use two in-house water standards in our fluorination line to check the stability of the measurements and to perform calibrations. The resulting pooled standard deviation for ${ }^{17} \mathrm{O}$-excess measurements is 5 per meg.

For this study with $\delta^{18} \mathrm{O}$ varying between -43 and $-38 \%$, we mainly used three in-house standards at around $-32,-40$ and $-58 \%$. These in-house standards are calibrated vs. V-SMOW (Vienna Standard Mean Ocean Water, $\delta^{18} \mathrm{O}=0 \% ;{ }^{17} \mathrm{O}$-excess $=0$ permeg) and SLAP (Standard Light Antarctic Precipitation, $\delta^{18} \mathrm{O}=-55.5 \%$; ${ }^{17}$ O-excess $=0$ permeg, Luz et al., 2009; Schoenemann et al., 2013). The calibration of our raw ${ }^{17} \mathrm{O}$-excess data can then be performed in two different ways. In a first attempt, we have simply subtracted from all raw ${ }^{17} \mathrm{O}$-excess data the ${ }^{17} \mathrm{O}$ excess difference between the measured and the calibrated standard at $-40 \%$. In a second attempt, we have used a twopoint calibration between measured and accepted values of V-SMOW and SLAP so that the ${ }^{17} \mathrm{O}$-excess correction increases with the $\delta^{18} \mathrm{O}$ difference between $\mathrm{O}_{2}$ obtained from the sample conversion and $\mathrm{O}_{2}$ obtained from V-SMOW conversion. We show in Fig. $3 \mathrm{~b}$ the comparison of ${ }^{17} \mathrm{O}$-excess evolution after these two corrections as well as the raw data. The general evolution of the ${ }^{17} \mathrm{O}$-excess profile and the particular separation in phases over GS-9 is not affected by the different corrections. 


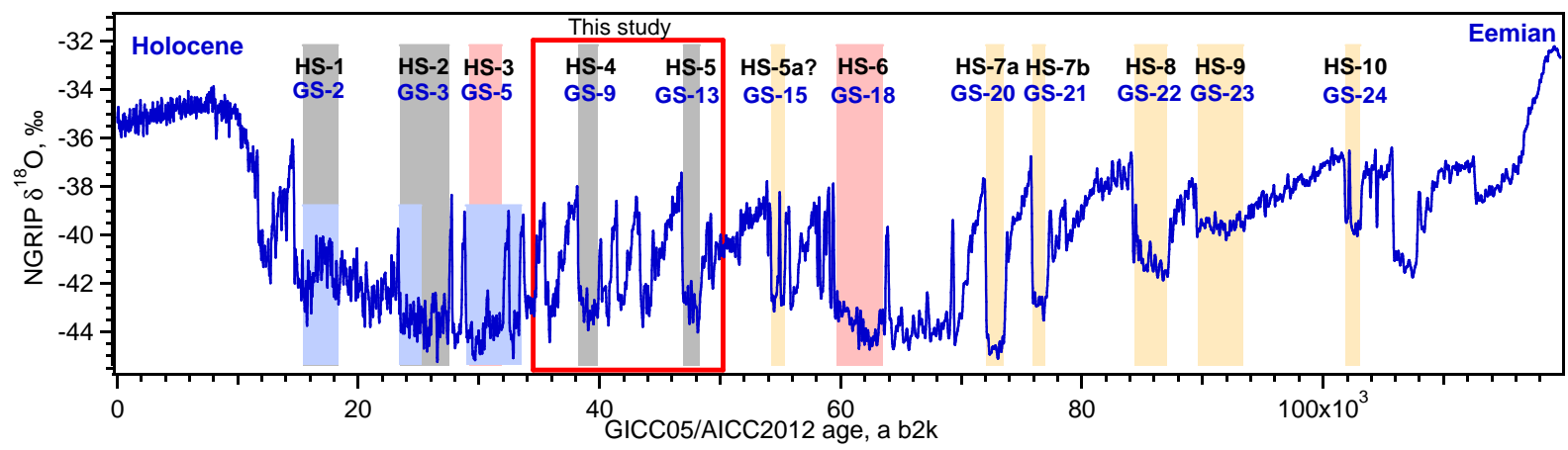

Figure 1. Dansgaard-Oeschger (the warm phases being marked as Greenland Interstadials, GI) and Heinrich Stadials (HSs) during the last glacial period. Blue line: NGRIP $\delta^{18} \mathrm{O}, \%$ (NGRIP members, 2004), on the GICC05 timescale back to $60 \mathrm{ka}$ b2k (Appendix A1) and AICC2012 beyond (Bazin et al., 2013; Veres et al., 2013). Coloured areas: Heinrich Stadials. Grey: HS-1, HS-2, HS-4 and HS-5: occurrence of a major Heinrich event of mainly Laurentide origin. Pink: HS-3 and HS-6, major events of mainly European origin (see text for references). Yellow: HS-5a and HS-7 to HS-10, occurrence of a minor IRD event of Laurentide origin recorded in the West Atlantic (Rashid et al., 2003; Rasmussen et al., 2003). Blue: periods of low salinity corresponding to freshwater input on the Celtic Margin (Eynaud et al., 2012).

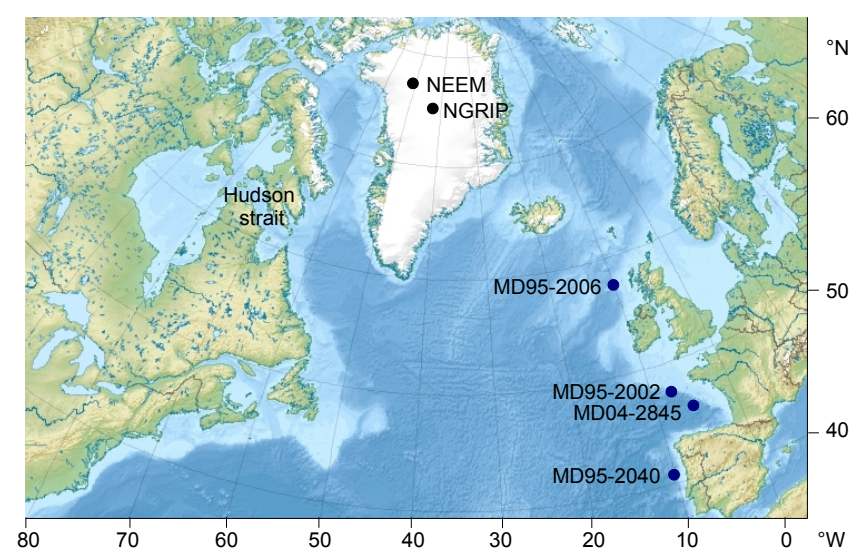

Figure 2. Map of the Northern Hemisphere palaeoclimate archives used in this study. Blue dots: marine cores. Black dots: ice cores. Most of the IRD for H4 and H5 were deposited by icebergs originating from the Laurentide ice sheet and delivered through Hudson Strait (Hemming, 2004). Background map from Uwe Dedering.

Finally, note that the measurements were done in three rounds, with a first series measured in spring 2011, a second one at the beginning of 2012 and a third one in spring 2014. Comparisons of the profiles are displayed in Fig. 3a after correction with the two-point calibration (V-SMOW vs. SLAP). The measurements were not necessarily performed over the same exact depth levels, which makes the inter-comparison less accurate. Both the mean levels and the variability are very coherent between the three ${ }^{17} \mathrm{O}$-excess profiles.

\section{$2.2 \delta^{18} O_{\text {atm }}$}

Our new $\delta^{18} \mathrm{O}_{\text {atm }}\left(\delta^{18} \mathrm{O}\right.$ of $\left.\mathrm{O}_{2}\right)$ data set measured on the NEEM ice core consists of 95 data points with replicates. A melt-refreeze technique has been used to extract the air from the ice samples. Our isotope ratio mass spectrometer is equipped with 10 Faraday cups to measure simultaneously the isotopic ratios $\delta^{18} \mathrm{O}$ and $\delta^{15} \mathrm{~N}$ as well as the elemental ratios $\mathrm{O}_{2} / \mathrm{N}_{2}$ (Landais et al., 2010).

To reconstruct the past $\delta^{18} \mathrm{O}_{\text {atm }}$ signal, $\delta^{18} \mathrm{O}$ measurements have been first corrected for eventual gas loss during ice storage using the $\delta \mathrm{O}_{2} / \mathrm{N}_{2}$ ratio measured in the same samples (more details can be found in Landais et al., 2010):

$$
\begin{aligned}
& \delta^{18} \mathrm{O}_{\text {gas loss corrected }}=\delta^{18} \mathrm{O}_{\text {measured }} \\
& +0.01\left(\delta \mathrm{O}_{2} / \mathrm{N}_{2}+10\right)
\end{aligned}
$$

The obtained data are then corrected for thermal and gravitational fractionation occurring in the firn. To do so, we use the isotopic composition of nitrogen $\delta^{15} \mathrm{~N}$ measured in the very same ice samples as well as firn modelling, to reconstruct the gravitational $\left(\delta^{15} \mathrm{~N}_{\text {grav }}\right)$ and thermal $\left(\delta^{15} \mathrm{~N}_{\text {therm }}\right)$ signals contributing to the measured $\delta^{15} \mathrm{~N}$ data (Guillevic et al., 2013; Landais et al., 2010, and references therein). The gravitational effect being proportional to the mass difference in between the two isotopes (Craig et al., 1988; Schwander, 1989), $\delta^{18} \mathrm{O}_{\text {grav }}$ is therefore twice as large as $\delta^{15} \mathrm{~N}_{\text {grav }}$. Temperature gradients in the firn create thermal fractionation of nitrogen and oxygen isotopes, and this effect is 1.6 times larger for $\delta^{18} \mathrm{O}$ compared to $\delta^{15} \mathrm{~N}$ due to differences in diffusivity coefficients (Severinghaus et al., 2001). The final $\delta^{18} \mathrm{O}_{\mathrm{atm}}$ is therefore obtained as follows:

$$
\begin{aligned}
& \delta^{18} \mathrm{O}_{\text {atm }}=\delta^{18} \mathrm{O}_{\text {gas loss corrected }}-1.6 \delta^{15} \mathrm{~N}_{\text {therm }} \\
& -2 \delta^{15} \mathrm{~N}_{\text {grav }} .
\end{aligned}
$$

The resulting $\delta^{18} \mathrm{O}_{\mathrm{atm}}$ pooled standard deviation is $0.03 \%$ (Landais et al., 2010). The $\delta^{18} \mathrm{O}_{\mathrm{atm}}$ data set is reported on the GICC05 timescale (Fig. 4f, black dots) using the NEEM gas age scale from Guillevic et al. (2013). The obtained profile is in agreement with previously published results from Severinghaus et al. (2009) measured on 


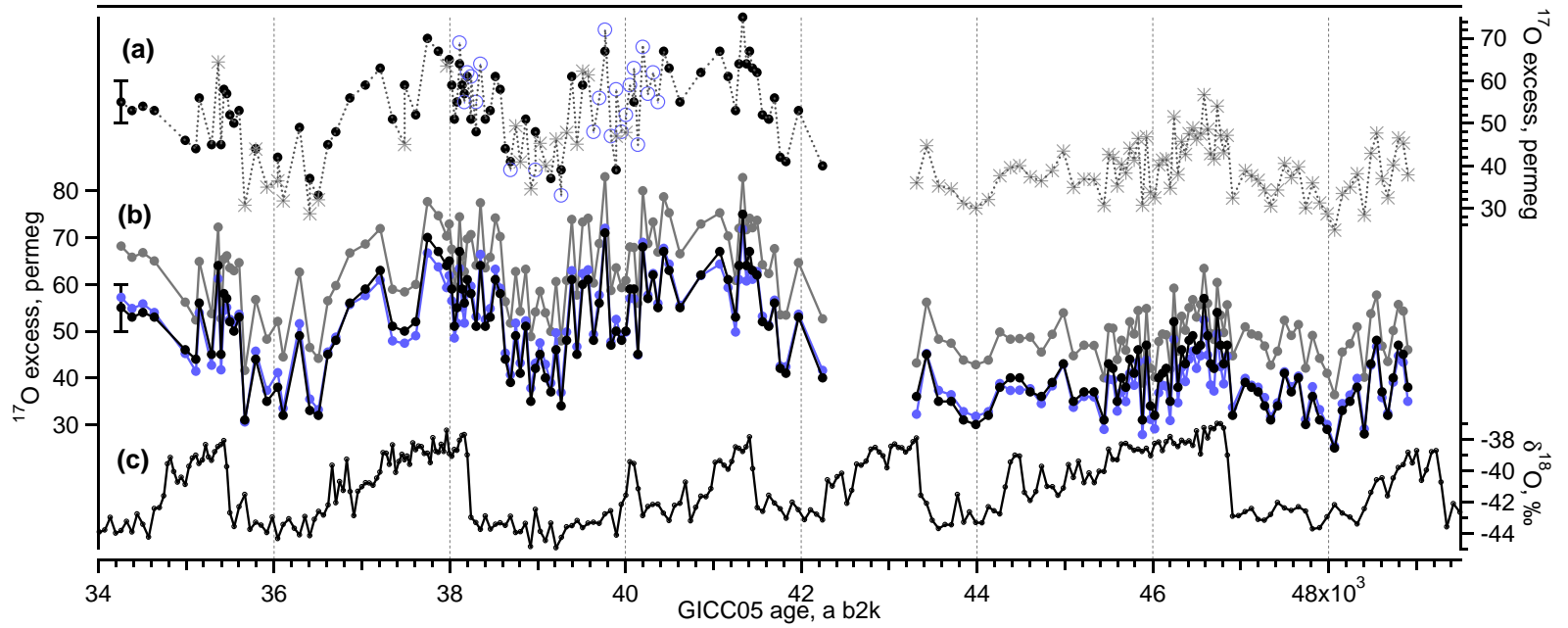

Figure 3. NEEM ${ }^{17} \mathrm{O}$-excess (per meg) and $\delta^{18} \mathrm{O}\left(\%\right.$ o data. (a) Comparison of the ${ }^{17} \mathrm{O}$-excess data measured in spring 2011 (black dots), at the beginning of 2012 (blue circles) and in winter 2013/spring 2014 (grey stars). (b) Calibration of the ${ }^{17}$ O-excess data. Grey dots: measured data; blue dots: one-point calibration; black dots: two-point calibration. (c) $\delta^{18} \mathrm{O}, \%$.

the Siple Dome ice core, Antarctica (Fig. 4f, grey dots). The advantage of using the NEEM rather than the Siple Dome $\delta^{18} \mathrm{O}_{\mathrm{atm}}$ data resides in the smaller NEEM ice-gas synchronisation uncertainty during GS-9 (Appendix A2).

\section{Results and discussion}

\section{$3.1 \quad{ }^{17} \mathrm{O}$-excess record}

The entire ${ }^{17} \mathrm{O}$-excess record covering GI-7 to GI-13 (Fig. 4d) shows a general correlation with the $\delta^{18} \mathrm{O}$ record and an anticorrelation with d-excess, while $\delta^{18} \mathrm{O}$ and $\mathrm{d}$ excess are themselves well anticorrelated: GI corresponds to high $\delta^{18} \mathrm{O}$ and ${ }^{17} \mathrm{O}$-excess levels and low d-excess levels, GS corresponds to low $\delta^{18} \mathrm{O}$ and ${ }^{17} \mathrm{O}$-excess levels and high d-excess levels. Following the current understanding of the ${ }^{17} \mathrm{O}$-excess proxy as given in introduction, such a general correlation with $\delta^{18} \mathrm{O}$ can be explained by (i) a synchronous change of high-latitude temperature and lower-latitude hydrological cycle (relative humidity at the oceanic source of evaporation or change in the water mass trajectory/recharge) and/or (ii) an influence of local temperature on ${ }^{17} \mathrm{O}$-excess through kinetic effect at snow formation. In addition to this general correlation with $\delta^{18} \mathrm{O}$, the high-resolution ${ }^{17} \mathrm{O}$ excess record reveals periods where ${ }^{17} \mathrm{O}$-excess is decoupled from $\delta^{18} \mathrm{O}$. The most obvious decoupling between $\delta^{18} \mathrm{O}$ and ${ }^{17} \mathrm{O}$-excess is observed during GS-9 (Fig. $4 \mathrm{~d}$, green arrows): ${ }^{17} \mathrm{O}$-excess decreases after the $\delta^{18} \mathrm{O}$ decrease at the beginning of GS-9 and increases several centuries before the $\delta^{18} \mathrm{O}$ increase at the beginning of GI-8. In fact, within GS-9 of constantly low $\delta^{18} \mathrm{O}$, we can infer three distinct phases from ${ }^{17} \mathrm{O}$ excess variations (Fig. 4d, Table B1): phase 1 (39 900-39 350 a b2k), corresponding to the beginning of GS-9, is marked by high ${ }^{17} \mathrm{O}$-excess values ( mean $=55$ per meg); phase 2 (39350-38610 a b2k) corresponds to low ${ }^{17} \mathrm{O}$-excess values (down to 34 per meg, mean $=42$ per meg); finally during phase 3 (38 610-38 220 a b2k) ${ }^{17} \mathrm{O}$-excess reaches high interstadial levels again (mean $=57$ per meg).

The decoupling observed between $\delta^{18} \mathrm{O}$ and ${ }^{17} \mathrm{O}$-excess implies that variations of ${ }^{17} \mathrm{O}$-excess during GS-9 cannot be due to local (Greenland) temperature changes. This conclusion is strengthened by an independent temperature reconstruction based on firn gas fractionation $\left(\delta^{15} \mathrm{~N}\right.$, Fig. $4 \mathrm{~b}$ and Guillevic et al., 2013) confirming a cold and stable temperature over the entire GS-9. The ${ }^{17} \mathrm{O}$-excess variations during GS-9 thus necessarily reflect changes in the organisation of the hydrological cycle of the lower latitudes, either through their impact on relative humidity at the source of evaporation, or through a change in the recharge of water along transportation towards Greenland. It is counter-intuitive that such changes in the evaporation conditions or moisture source do not affect the d-excess signal. While we do not have a definite explanation for the lack of signal in the d-excess record, we already know that d-excess in Greenland is much more sensitive to local temperature changes than ${ }^{17} \mathrm{O}$-excess (Winkler et al., 2012; Landais et al., 2012b). Moreover, because of its linear definition, d-excess is not sensitive to mixing of different water masses along the trajectory. A simple mathematical calculation (Risi et al., 2010) shows that the mixing of two water vapour masses with similar $\mathrm{d}$-excess and ${ }^{17} \mathrm{O}$-excess but different $\delta^{18} \mathrm{O}$ produces a stable d-excess but a decrease in ${ }^{17} \mathrm{O}$-excess.

Because of the complexity of processes which may be responsible for the specific ${ }^{17} \mathrm{O}$-excess signal, it is thus important to confront our finding to other low-latitude proxies registered in Greenland ice cores, to independently confirm 


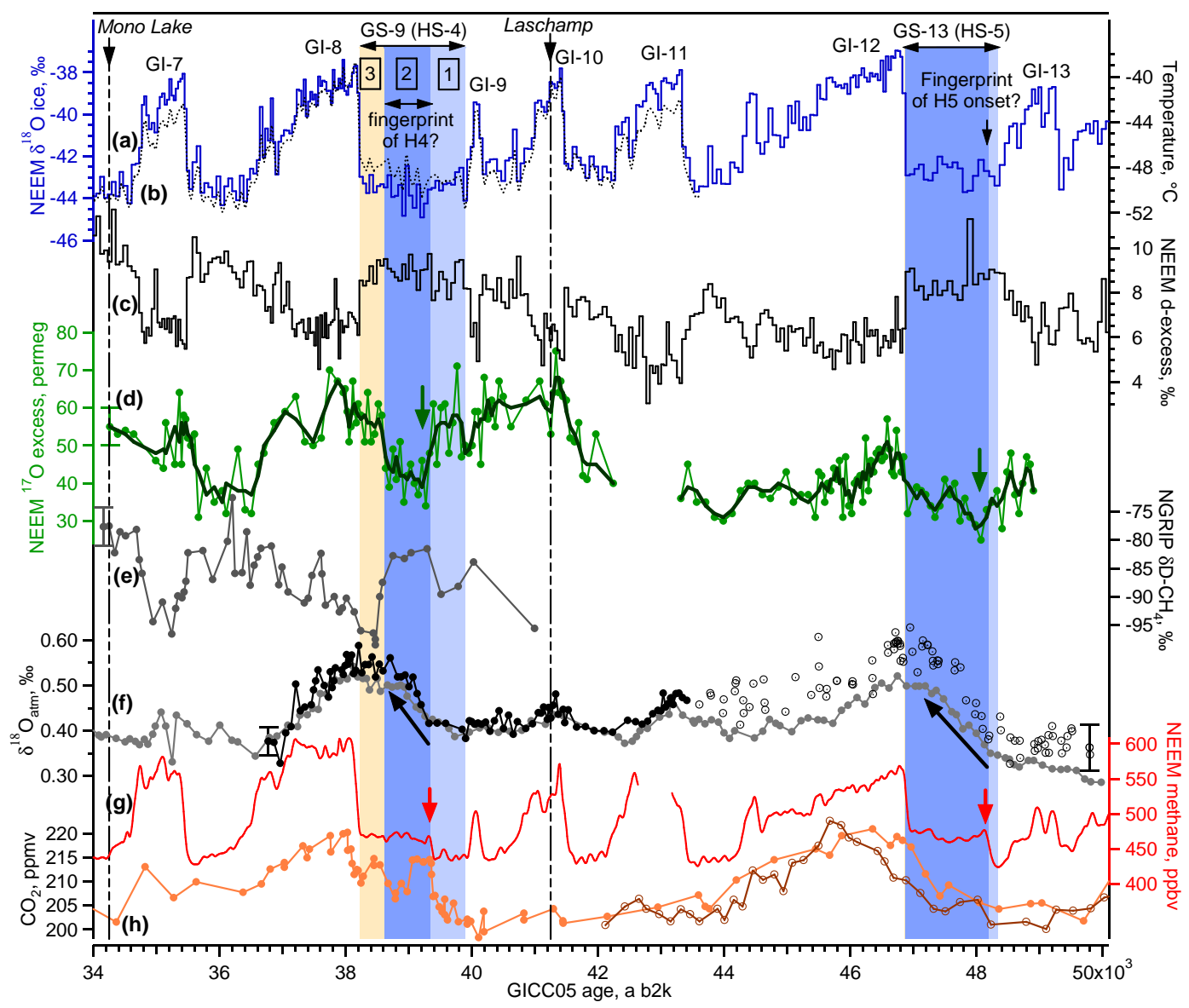

Figure 4. Greenland and Antarctic ice core records surrounding Heinrich events 4 and 5, synchronised to the GICC05 timescale (Appendix A). Position of phase 1 (light blue area), phase 2 (blue area) and phase 3 (yellow area) as given in Table B1. Dashed-dotted vertical lines: position of the geomagnetic excursion events Mono Lake and Laschamp (Svensson et al., 2006, 2008). (a) Blue line: NEEM $\delta^{18} \mathrm{O}$ ice, $\% o$ (precision: 0.07\%o) (Guillevic et al., 2013). (b) Black dotted line: NEEM temperature reconstructed using $\delta^{15} \mathrm{~N}$ data and firn modelling (Guillevic et al., 2013). (c) Black: NEEM deuterium excess, \%o $( \pm 0.7 \%$ ), this study, measured at LSCE (France). (d) Green dots: NEEM ${ }^{17}$ O-excess, per meg ( \pm 5 per meg), this study, measured at LSCE. Each dot corresponds to the average over $55 \mathrm{~cm}$ of ice. Green line: threepoint running average. (e) Dark grey: NGRIP $\delta \mathrm{D}-\mathrm{CH}_{4}, \%_{0}\left( \pm 3.4 \%\right.$ ) (Bock et al., 2010). (f) Black dots: $\mathrm{NEEM} \delta{ }^{18} \mathrm{O}_{\mathrm{atm}}, \%$ $( \pm 0.03 \%$ ), this study, measured at LSCE. Black circles: NGRIP $\delta^{18} \mathrm{O}_{\text {atm }}$ (Huber et al., 2006). Grey dots: Siple Dome $\delta^{18} \mathrm{O}_{\text {atm }}($ Severinghaus et al., 2009). (g) Red: NEEM methane mixing ratio, ppbv ( \pm 5 ppbv), record measured by the CIC instrument (Chappellaz et al., 2013). (h) $\mathrm{CO}_{2}$ mixing ratio, ppmv. Orange dots: Byrd ice core, Antarctica (Ahn et al., 2012). Brown open circles: TALDICE ice core, Talos Dome, Antarctica (Bereiter et al., 2012).

the decoupling between Greenland and lower latitudes during GS-9 as highlighted by the ${ }^{17} \mathrm{O}$-excess record.

\subsection{Multi-proxy identification of a three-phase sequence during GS-9 contrasting with the more uniform GS-8, 11 and 12}

Our new high-resolution $\delta^{18} \mathrm{O}_{\text {atm }}$ measurements of air entrapped in the NEEM ice core confirm a decoupling between Greenland temperature and lower-latitude water cycle over GS-9. Indeed, earlier studies have shown that millennial $\delta^{18} \mathrm{O}_{\text {atm }}$ variations are global responses to water cycle changes in the northern Tropics (Severinghaus et al., 2009; Landais et al., 2010), where ITCZ shifts drive changes in pre- cipitation isotopic composition (Lewis et al., 2010; Pausata et al., 2011). Our 95 new measurements of $\delta^{18} \mathrm{O}_{\text {atm }}$ depict a stable, low $\delta^{18} \mathrm{O}_{\text {atm }}$ during phase 1 , followed by an increase over phase $2(+0.14 \%$, Fig 4 f, black arrow), and finally a stable high plateau during phase 3 , in agreement with the Siple Dome record (Fig. 4f). The onsets of changes of $\delta^{18} \mathrm{O}_{\text {atm }}$ and ${ }^{17} \mathrm{O}$-excess occur synchronously at the beginning of phase 2 (ice-gas synchronisation uncertainty less than \pm 100 a for the NEEM record, Appendix A2), but the increase of $\delta^{18} \mathrm{O}_{\mathrm{atm}}$ is much slower than the observed changes in ${ }^{17} \mathrm{O}$-excess; this is expected because of the long residence time of oxygen in the atmosphere (1000-2000 a, Bender et al., 1994a; Hoffmann et al., 2004). Second, in addition to the $\delta^{18} \mathrm{O}_{\mathrm{atm}}$ record, records of $\mathrm{NEEM} \mathrm{CH}_{4}$ (Fig. $4 \mathrm{~g}$ 
Chappellaz et al., 2013) and its hydrogen isotopic composition (Fig. 4e, NGRIP $\delta \mathrm{D}-\mathrm{CH}_{4}$, Bock et al., 2010) in the air trapped in ice core also exhibit significant variations during GS-9 that are synchronous with the three phases identified from the ${ }^{17} \mathrm{O}$-excess variations. Phase 1 is characterised by a minimum in methane mixing ratio, whereas the onset of phase 2 is marked by a $20 \mathrm{ppb}$ abrupt increase (Fig. $4 \mathrm{~g}$, red arrow) accompanied by a $8 \pm 4.8 \%$ increase in $\delta \mathrm{D}-\mathrm{CH}_{4}$. At the onset of phase 2, the concomitant changes in $\mathrm{CH}_{4}$, $\delta \mathrm{D}-\mathrm{CH}_{4}, \delta^{18} \mathrm{O}_{\mathrm{atm}}$ and ${ }^{17} \mathrm{O}$-excess in the absence of any Greenland temperature change can consistently be explained by a low-latitude change in water cycle as induced by a southward shift of the ITCZ.

Concerning the measured increase in $\delta \mathrm{D}-\mathrm{CH}_{4}$ at the onset of phase 2, such a shift would also be in agreement with model simulations of the clathrate release signature in ice cores (Bock et al., 2012), and is also supported by the synchronously lighter $\delta^{13} \mathrm{C}-\mathrm{CH}_{4}$ anomaly recently measured in the EDML ice core (Möller et al., 2013). We thus cannot exclude a sudden clathrate release at the onset of phase 2 that might be caused by e.g. less dense water masses in the North Atlantic Ocean following e.g. a massive iceberg discharge, as modelled by Flückiger et al. (2006). Higherresolution methane isotopic data would be necessary to investigate in detail this possibility. However, the long duration of the $\delta \mathrm{D}-\mathrm{CH}_{4}$ anomaly (phase 2,740 a) as well as the stable plateau of methane mixing ratio and $\delta^{13} \mathrm{C}-\mathrm{CH}_{4}$ throughout phases 2 and 3 (1130 a) call for an additional mechanism, such as source mix change or/and heavier isotopic composition of tropical precipitation (Möller et al., 2013) at the onset of phase 2 . The mixing ratio increase and the following plateau are consistent with the activation of new methane sources in e.g. South America as simulated by Hopcroft et al. (2011), associated with a southward ITCZ shift at the onset of phase 2. Moreover, such a southward ITCZ shift is expected to produce more depleted precipitation in the SH (Southern Hemisphere) Tropics and heavier precipitation in the NH (Northern Hemisphere) Tropics (Pausata et al., 2011; Lewis et al., 2010). The increase in both $\delta \mathrm{D}-\mathrm{CH}_{4}$ and $\delta^{18} \mathrm{O}_{\mathrm{atm}}$ at the onset of phase 2 are consistent with this mechanism, provided that NH Tropics remain the main source of methane and oxygen. A minor part of the $\delta \mathrm{D}-\mathrm{CH}_{4}$ increase can be due to oxidation of methane in the troposphere, consuming preferentially the light methane isotopologues, if the mean atmospheric temperature decreases at the onset of phase 2 (Lewis et al., 2010; Bock et al., 2010; Sowers, 2006; Levine et al., 2012).

Finally, two abrupt $\sim 20 \mathrm{ppm}$ increases in the atmospheric $\mathrm{CO}_{2}$ concentration recently unveiled from high-resolution Antarctic ice core records occur at the onsets of phase 2 and phase 3 (Fig. 4h and Ahn et al., 2012). After Antarctic and Greenland gas record synchronisation through $\mathrm{CH}_{4}$ (Appendix A2), our study evidences that the $\mathrm{CO}_{2}$ rise at the onset of phase 2 is synchronous $( \pm 100$ a) with a southward shift of the ITCZ, as suggested by the other NEEM ice core proxy variations. Different mechanisms are proposed to explain this $\mathrm{CO}_{2}$ rise, as already discussed in Ahn et al. (2012): most probably upwelling in the Southern Ocean around Antarctica as suggested by increased opal burial rates in marine cores (Anderson et al., 2009), with a potential minor contribution from upwelling off the NW African coast (Jullien et al., 2007; Itambi et al., 2009; Mulitza et al., 2008). The causes of such modifications of the oceanic carbon storage may involve strengthening and/or southward shift of the SH westerlies, and/or AMOC slow down, and therefore remain debated (e.g. Toggweiler et al., 2006; Völker and Köhler, 2013; Menviel et al., 2014).

Altogether, our multi-proxy ice core data set reveals a 740 a long period starting 550 a after the onset of GS-9 (phase 2), which is marked by a southward shift of the ITCZ. The transition to phase 3 is characterised by reversed variations, with ${ }^{17} \mathrm{O}$-excess and $\delta \mathrm{D}-\mathrm{CH}_{4}$ reaching interstadial values $480 \pm 50$ a prior to the increase in $\delta^{18} \mathrm{O}$ marking the onset of GI-8. We explain this pattern by a gradual northward shift of the ITCZ associated with lighter precipitation in the NH Tropics and heavier precipitation in the SH Tropics. The flat methane and $\delta^{18} \mathrm{O}_{\mathrm{atm}}$ records suggest a globally stable methane budget and biosphere productivity, possibly due to compensating effects at different latitudes.

The sequence of events identified during HS-4 contrasts with the other non-Heinrich stadials where the pattern of changes recorded in Greenland $\delta^{18} \mathrm{O}$ and other proxy records mostly depict a GS/GI contrast. These other GS are mostly characterised by low $\delta^{18} \mathrm{O}$ and ${ }^{17} \mathrm{O}$-excess levels, low methane mixing ratio (without any plateau) and slightly increasing $\delta^{18} \mathrm{O}_{\text {atm }}$ (compared to the strong increase observed during HS-4). We therefore underline that the three-phase sequence identified during HS-4 is really specific and should not be applied to the other stadials studied here.

Some fingerprints of the decoupling between high and low latitudes identified during HS-4 can also be evidenced during HS-5 (or GS-13) even though less proxy data are currently available. We observe synchronous $\delta^{18} \mathrm{O}_{\mathrm{atm}}$ and methane increases about $140 \pm 40 \mathrm{a}$ after the beginning of GS-13, at $48200 \mathrm{a}$ b2k on the GICC05 chronology, $1340 \pm 80$ a before the onset of GI-12 (Fig. 4f and g, black and red arrows). This shift is accompanied by a small ${ }^{17} \mathrm{O}$-excess decrease (Fig. 4d, green arrow). The $\mathrm{CO}_{2}$ increase that was clear at the onset of phase 2 during GS-9 is however much less pronounced or perhaps even absent at the onset of phase 2 during GS13 ( $+5 \mathrm{ppm}$ in TALDICE, less clear in the Byrd $\mathrm{CO}_{2}$ record, Bereiter et al., 2012; Ahn et al., 2012, and Fig. 4h). Finally, based on the available data we do not observe any decoupling between Greenland and lower latitudes toward the end of GS-13 as was observed over the phase 2 to phase 3 transition during GS-9. However, $\delta \mathrm{D}-\mathrm{CH}_{4}$ data are lacking during this time period and we cannot draw any firm conclusion here. 


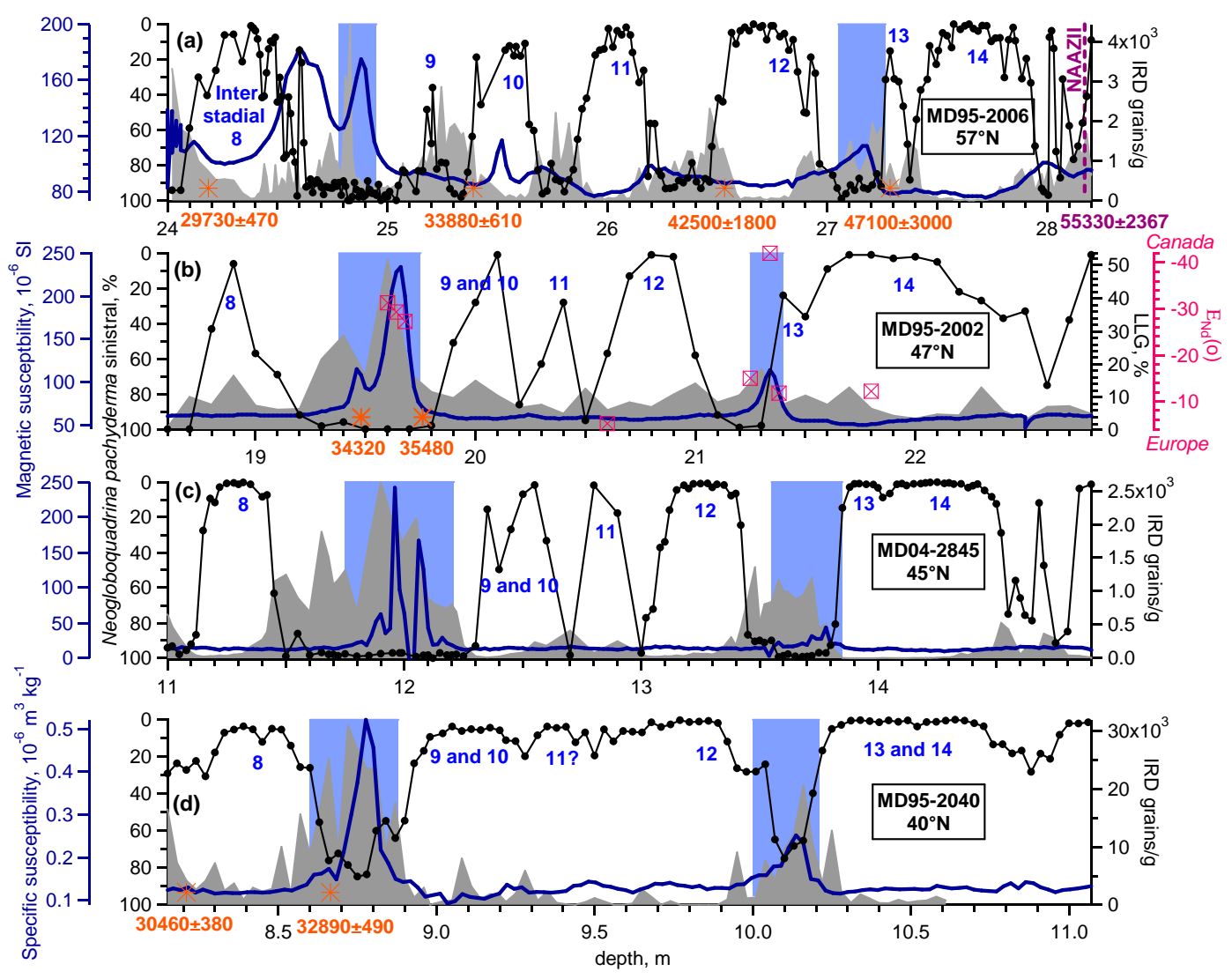

Figure 5. H4 and H5 in marine sediment records from the European margin. Core localisations are shown in Fig. 2. Each core is on its

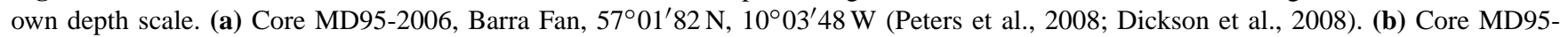
2002, Celtic margin, $47^{\circ} 27^{\prime} 12 \mathrm{~N}, 8^{\circ} 27^{\prime} 03 \mathrm{~W}$ (Auffret et al., 2002). (c) Core MD04-2845, Bay of Biscay, $45^{\circ} 21^{\prime} \mathrm{N}, 5^{\circ} 13^{\prime} \mathrm{W}$ (Sánchez Goñi et al., 2008). (d) Core MD95-2040, Portuguese margin, 40³4'91 N, 951'67 W (de Abreu et al., 2003; Eynaud et al., 2009). Orange stars: uncalibrated carbon 14 age measurements (a before 1950 AD) and associated analytical uncertainties. Violet star: NAAZ (North Atlantic Ash Zone) II (Austin et al., 2004) and associated GICC05 age (a before 1950 AD) and MCE (Svensson et al., 2008). Grey shaded area: IRD or LLG (large lithic grains), counted on the $>150 \mu \mathrm{m}$ fraction. Black line and dots: abundance of the polar foraminifer $N$. pachyderma sinistral, $\%$; a high percentage denotes cold sea surface temperature. Blue line: magnetic susceptibility (a, b, c) and specific susceptibility (d). Pink squares: $\epsilon$ neodymium $(\mathrm{Nd})$ of the lithic coarse fraction $(>150 \mu \mathrm{m})$. Low values $(\leq 40)$ characterise sediment of Canadian origin, higher values $(\geq 15)$ European origin. Blue shaded areas: possible Laurentide contribution to the IRD/LGG. Origin identification of IRD for core MD95-2006 based on mineral magnetic measurements (for H4 and H5, Peters et al., 2008) and an additional unpublished count of detritial carbonate grains (for H4, W. Austin, personal communication, 2014), on $\epsilon$ neodymium and magnetic susceptibility for core MD95-2002 (Auffret et al., 2002) and on magnetic susceptibility (as proposed by Thouveny et al., 2000, for the Iberian Margin) for cores MD04-2845 (Sánchez Goñi et al., 2008) and MD95-2040 (de Abreu et al., 2003).

\subsection{Comparison with marine core records from the North Atlantic}

Low/mid-latitude palaeoclimate archives have already provided information on climate variations during Greenland stadials and especially over Stadial 9 (e.g. Voelker et al., 2006; Skinner and Elderfield, 2007). In particular, several phases have already been identified in sediment cores off the European margin and especially off Iberia, based on pollen assemblages and charcoal records (Naughton et al., 2009; Daniau et al., 2009): in the first phase, before the IRD layer and until the maximum IRD content is reached, the climate follows a progressively cooler and wetter trend. In the sec- ond phase after the IRD peak response, the climate is on the contrary progressively drier, with more frequent fire regime episodes.

Hereafter, we combine North Atlantic marine cores from different latitudes along the European margin, located between 5 to $10^{\circ} \mathrm{W}$ and 40 to $57^{\circ} \mathrm{N}$ (Figs. 2 and 5). Note that in Fig. 5, each marine sediment core is on its own depth scale. The available chronological control points are ${ }^{14} \mathrm{C}$ measurements (in orange) and the NAAZ-II (North Atlantic Ash Zone II) tephra layer also identified in the NGRIP ice core (in violet, see figure for references). We have only reported the ${ }^{14} \mathrm{C}$ measurement values and associated analytical uncertainties when available, without reservoir age correction or 
calibration to calendar ages. Indeed, for this time period the ${ }^{14} \mathrm{C}$ measurement uncertainties (minimum \pm 380 years here) and their scarcity already prevent any centennial-scale synchronisation of these marine sediment cores.

We hereafter compare in each core the relative timing of changes in Neogloboquadrina pachyderma sinistral percentage (a proxy for sea surface temperature, black dots in Fig. 5) with the potential Laurentide IRD deposition (blue bars in Fig. 5, see Thouveny et al., 2000; Auffret et al., 2002; Peters et al., 2008, for details). As for the multi-proxy study of GS-9 in ice cores, the multi-proxy study of these marine cores in the European margin shows some latitudinal decoupling during stadial 9: (i) prior to the Laurentide IRD delivery, cold conditions are already depicted in the eastern part of the so-called Ruddiman belt (Ruddiman, 1977), at $45-55^{\circ} \mathrm{N}$ (e.g. Fig. 5a, core MD95-2006, Peters et al., 2008; Dickson et al., 2008), while interstadial conditions persist around the Iberian Peninsula at $35-42^{\circ} \mathrm{N}$ (e.g. Fig. $5 \mathrm{~d}$, core MD95-2040, de Abreu et al., 2003); (ii) the onset of the Laurentide IRD delivery coincides with a possible further cooling at high latitudes, while Iberia enters into cold stadial conditions; (iii) once low Laurentide IRD levels are registered again, mild to interstadial conditions are recorded around the Iberian Peninsula, while cold temperatures persist at $45-55^{\circ} \mathrm{N}$. Between 40 and $57^{\circ} \mathrm{N}$, cores MD04-2845 and MD95-2002 suggest that the situation might be intermediate, with a slight lag of the Laurentide IRD layer behind the polar species N. pachyderma sinistral increase (Fig. 5b, c, Auffret et al., 2002; Sánchez Goñi et al., 2008). Higher-resolution data as well as climate-independent synchronisation tools in between marine cores (such as measurements to detect specific palaeomagnetic events and/or volcanic ash layers) are necessary for a better description.

Over stadial 9, chronological uncertainties prevent us to link ice cores to other archives at a centennial year resolution, due to uncertainties in the GICC05 timescale $( \pm 1574$ a at $40000 \mathrm{a}$ b2k, Svensson et al., 2008) and in ${ }^{14} \mathrm{C}$ measurement, reservoir age and calibration curve for marine sediment cores (Fig. 5 and e.g. Reimer et al., 2013). However, we still note that such a southward ITCZ shift can explain both the fingerprints in $\mathrm{CH}_{4}, \delta \mathrm{D}-\mathrm{CH}_{4},{ }^{17} \mathrm{O}$-excess and $\delta^{18} \mathrm{O}_{\mathrm{atm}}$, as well as the colder conditions registered in the Iberian Peninsula that correspond to the purge of the LIS, i.e. the beginning of H4. Indeed, the H4 iceberg discharge could lead to European cooling as well as southward ITCZ shift, as simulated by climate models (Chiang et al., 2008). With this assumption, the inferred start of $\mathrm{H} 4$ would be $39350 \pm 1520$ a b2k on the GICC05 chronology.

During phase 3, we note a progressive shift towards interstadial conditions first indicated by lower-latitude ice core proxies (Fig. 4, $\delta \mathrm{D}-\mathrm{CH}_{4},{ }^{17} \mathrm{O}$-excess). This would be consistent with a progressive northwards progression of the climate recovery towards interstadial climate conditions. This is in agreement with marine cores from low/mid-latitudes suggesting the start of a progressive AMOC recovery before full interstadial climate conditions are reached (e.g. Vautravers et al., 2004). The combination of ice and marine core data therefore supports the following sequence of events in phase 3 : end of the iceberg delivery in the North Atlantic, northwards shift of the ITCZ and progressive AMOC restart, and finally the abrupt Greenland warming.

Finally, while some common characteristics can be drawn for HS-4 and 5, further studies are needed to assess whether this can be applied to the other Heinrich stadials or not. Considering the different background climate states and origin of the ice sheet collapse for the other HEs (Fig. 1), a different sequence identification in the ice core records can be expected.

\subsection{How realistic is a decoupling between Greenland temperature and lower-latitude changes in climate and hydrological cycle?}

Our study shows that a change in the mid/low latitudes of the North Atlantic ocean happens after the beginning of GS9 , with a time lag of $550 \pm 60$ a, i.e. when the North Atlantic region has already entered a cooling trend. Some features of our study suggest that the same may be true for GS13 with a decoupling between Greenland temperature and lower-latitude climate $140 \pm 40$ a after the beginning of GS13. We have hypothesised that this change may be linked to iceberg deliveries, i.e. $\mathrm{H} 4$ and $\mathrm{H} 5$. This assumption is actually supported by recent studies investigating the triggering mechanisms of HEs. Indeed, it has been suggested that the Northern Atlantic temperature decrease (beginning of GS in our case) is concomitant with the onset of a progressive AMOC slow-down and shoaling accompanied by sea ice extent that isolate the subsurface ocean from the cold atmosphere and produce a subsurface warming (Rasmussen and Thomsen, 2004; Jonkers et al., 2010). In addition, this subsurface warming could lead to a sea-level rise of $\sim 0.5$ to $1 \mathrm{~m}$ by reorganisation of the North Atlantic dynamic topography and by oceanic thermal expansion (as modelled in Shaffer et al., 2004; Flückiger et al., 2006). Both subsurface warming and sea-level rise then contribute to destabilising ice shelves from the massive Laurentide ice sheet, causing the massive iceberg delivery of Heinrich events occurring several centuries after the onset of the Greenland stadials (Alvarez-Solas et al., 2010; Alvarez-Solas and Ramstein, 2011; Marcott et al., 2011).

The suggestion that HEs 4 and 5 occur after the beginning of Greenland stadials calls for another mechanism to trigger stadial conditions. Recent studies listed hereafter have proposed a local (Arctic) control on DO events, without the need of a freshwater flux into the North Atlantic Ocean. (i) The studies of Norwegian Sea marine sediment cores from Rasmussen and Thomsen (2004) and Dokken et al. (2013) proposed that stadials were induced by progressively increasing winter sea ice cover in the Nordic seas and the formation of a halocline isolating warm subsurface waters from 
the North Atlantic drift from the atmosphere. (ii) These studies also showed IRD from the Fennoscandian ice sheet during the warm phases of DO events. The authors proposed that the corresponding freshwater flux helped to establish a halocline and hereby facilitated sea ice formation, inducing a cooling towards a stadial climate. A model study from Roche et al. (2010) has moreover shown that the overturning cell in the Nordic seas is very sensitive to freshwater perturbations, even more than the Ruddiman belt in the North Atlantic. (iii) Finally, a third mechanism (that could be combined with the two previous ones) has been proposed by Petersen et al. (2013): the onset of GI could be induced by the collapse of an ice shelf east of Greenland extending towards Denmark Strait, due to subsurface melt. The slow regrowth together with the expansion of regional sea ice cover would create the progressive cooling towards GS. Moreover, these three mechanisms could explain why the Nordic seas (and Greenland) remain in a stable stadial state, while low/mid-latitudes are gradually shifting towards interstadial conditions (as suggested by the increased ${ }^{17} \mathrm{O}$ excess during phase 3 ): during stadials, the heat advected along the North Atlantic Drift accumulates in subsurface, below the sea ice in the Nordic seas or below the ice shelf east of Greenland, until the low-density warm subsurface water abruptly reaches the surface, thereby melting the sea ice and/or ice shelf, which results in a rapid warming of the Nordic seas (and Greenland).

These different mechanisms calling for a local Arctic control on DO events are supported by model studies. Indeed, atmospheric simulations (Li et al., 2010) suggest that Greenland temperature is sensitive to changes in sea ice cover anomalies in the Nordic seas because of "a strengthening of the easterly flow over the Nordic seas" impacting Central Greenland. In contrast, in these simulations, NW Atlantic sea ice cover anomalies (supposed to increase during HEs originating from the Laurentide) only affect the western flank of the Icelandic low and the associated atmospheric circulation anomaly does not noticeably impact Central Greenland. Supporting these results, the modelled regional pattern of Greenland warming in response to Nordic seas sea ice retreat is in agreement with regional quantitative reconstruction of Greenland temperature and accumulation rate during MIS3 (Guillevic et al., 2013).

From our data, we found that central Greenland temperature is not sensitive to lower-latitude climate changes during stadials. This is actually not a unique case. Other palaeoclimate archives show the same insensitivity, e.g. no specific sea ice change is depicted during the entire stadial 9 as inferred from deep sea core records obtained from the Irminger Sea and south of the Faroe Islands (Cortijo et al., 2005; Zumaque et al., 2012).

However, bio-indicators in marine cores from the Norwegian Sea robustly record warmer temperature (e.g. based on foraminifers, Rasmussen and Thomsen, 2004; Dokken et al., 2013) and reduced sea ice cover (based on dinocysts, Eynaud et al., 2002) during stadials than during interstadials. To rec- oncile these conflicting model-data results, Rasmussen and Thomsen (2004) and Dokken et al. (2013) proposed a perennial sea ice cover in the Norwegian Sea during all stadials of MIS3, separated by a halocline from warm subsurface waters in the North Atlantic Drift, to where foraminifers might have moved their depth habitat. Dinocysts on the contrary may have stayed at the surface, and their observed assemblages could be due to productivity anomalies in zones of polynya. According to this scenario, the lack of specific sea ice anomaly in the Nordic seas during GS-9 and GS-13 may explain why no cold anomaly is recorded in Greenland during the same periods.

The proposed decoupling between cold, stable Greenland temperature and lower-latitude climatic changes during stadial 9 has implications for synchronisation of climate archives from different latitudes. For the last glacial period, chronologies of sediment cores from the North Atlantic and Europe are usually constructed by wiggle matching of DOlike variations to the NGRIP $\delta^{18} \mathrm{O}$ record on its GICC05 chronology. While it has been underlined by several studies that there were no independent chronological support for this hypothesis (Blaauw et al., 2010), the decoupling between ${ }^{17} \mathrm{O}$ excess and $\delta^{18} \mathrm{O}$ variations during GS-9 suggests that this would actually not be correct for this specific time period. We therefore would like to emphasise the need of highresolution climate-independent synchronisation tools, such as volcanic ash layers, as already widely encouraged by the INTIMATE working group (e.g. Austin and Hibbert, 2012; Davies et al., 2014; Brendryen et al., 2011).

\section{Conclusions and perspectives}

Here, we have presented the first ${ }^{17} \mathrm{O}$-excess record from a Greenland ice core covering a sequence of DO events during the last glacial period, and encompassing two major HEs of Laurentide origin. The ${ }^{17} \mathrm{O}$-excess profile shows generally high values during GI and low values during GS periods. This can be interpreted as synchronous change of high-latitude temperature and lower-latitude hydrological cycle (relative humidity at the oceanic source of evaporation or change in the water mass trajectory/recharge) and/or an influence of local temperature on ${ }^{17} \mathrm{O}$-excess through kinetic effect at snow formation. However, especially during GS-9, the ${ }^{17} \mathrm{O}$-excess record shows additional variability that cannot be identified either in the $\delta^{18} \mathrm{O}$ or in the d-excess records. The decoupling observed between $\delta^{18} \mathrm{O}$ and ${ }^{17} \mathrm{O}$-excess implies that variations of ${ }^{17} \mathrm{O}$-excess during GS-9 cannot be due to local (Greenland) temperature changes.

Our new multi-proxy record from Greenland ice cores has revealed a three-phase sequence of GS-9, contrasting with the more stable GS-8, 11 and 12. While Greenland temperature remains uniformly cold along GS-9, synchronous changes in ${ }^{17} \mathrm{O}$-excess, $\delta{ }^{18} \mathrm{O}_{\mathrm{atm}}, \delta \mathrm{D}-\mathrm{CH}_{4}$, methane and $\mathrm{CO}_{2}$ are interpreted as a polar ice core fingerprint of the lower- 
latitude climate and hydrological cycle changes, most likely due to a southward shift of the ITCZ delayed by $550 \pm 60$ a after the beginning of the cold period in Greenland (GS9). We hypothesise that this lower-latitude change dated at $39350 \pm 1520$ a b2k on the GICC05 chronology may be associated with the strong Heinrich event 4 . This is in agreement with recent data and modelling studies suggesting that the iceberg discharge only occurs several centuries after the cooling of surface ocean in North Atlantic and decrease of AMOC intensity.

The fingerprint of the ITCZ southward shift observed in ice core proxies ends $740 \pm 60$ a later, when ${ }^{17} \mathrm{O}$-excess, $\delta^{18} \mathrm{O}_{\text {atm }}$ and $\delta \mathrm{D}-\mathrm{CH}_{4}$ have shifted back to interstadial climate values, $390 \pm 50$ a before the onset of GI-8. Preliminary investigations on GS-13 encompassing H5 suggest an ITCZ southward shift fingerprint based on the ice core proxies $\delta^{18} \mathrm{O}_{\mathrm{atm}}$ and $\mathrm{CH}_{4}, 140 \pm 40 \mathrm{a}$ after the beginning of GS-13. In opposite to what happens during HS-4, the ${ }^{17} \mathrm{O}$-excess variations are less significant here and we cannot identify three phases for HS-5. Our findings obviously call for systematic and high-resolution investigations of the ice core multi-proxy fingerprints of lower-latitude climate changes in general and HEs in particular.
In contrast to the more stable and uniform non-Heinrich stadials, the decoupling between the constantly cold Greenland temperature during GS-9 and the climate variability associated with $\mathrm{H} 4$ at lower latitudes challenges the use of Greenland ice core temperatures as a single target for benchmarking climate simulations focused on HEs. Our multiproxy study opens new paths for parallel investigations of different marine, terrestrial and ice core climate archives. 
Appendix A: Synchronisation of the used ice cores to the GICC05 chronology

\section{A1 Ice age scales}

The GICC05 (Greenland Ice Core Chronology 2005) has been constructed for the NGRIP ice core from present back to $60 \mathrm{ka} \mathrm{b2k}$ based on annual layer counting in ice cores of parameters featuring seasonal scale variations (Vinther et al., 2006; Andersen et al., 2006; Rasmussen et al., 2006; Svensson et al., 2008). The NEEM ice core (Rasmussen et al., 2013) has been synchronised to NGRIP using match points based on peaks of electrical conductivity and dielectrical properties of the ice. The synchronisation uncertainty between NEEM and NGRIP is estimated to be $\sim 10 \mathrm{~cm}(1 \sigma$, Rasmussen et al., 2013), resulting in $\sim 10$ a synchronisation uncertainty for GS-9. The GICC05 uncertainty is estimated by the maximum counting error in years (Rasmussen et al., 2006), with each uncertain year counted as $0.5 \pm 0.5 \mathrm{a}$. This can be considered as a $2 \sigma$ uncertainty. We give the duration uncertainty of each of the phases of GS-9 and GS-13 as the sum of the uncertain years counted within each phase.

Table A1. Match points between methane depths from the Byrd ice core (Ahn and Brook, 2008; Ahn et al., 2012), the Siple Dome ice core (Brook et al., 2005; Ahn et al., 2012) and NEEM methane (Chappellaz et al., 2013) gas age according to the GICC05 chronology (Guillevic et al., 2013; Rasmussen et al., 2013).

\begin{tabular}{lccc}
\hline Event & $\begin{array}{c}\text { Byrd } \\
\text { depth [m] }\end{array}$ & $\begin{array}{c}\text { Siple Dome } \\
\text { depth [m] }\end{array}$ & $\begin{array}{c}\text { NEEM methane } \\
\text { gas age, [a b2k] }\end{array}$ \\
\hline GI-6 & 1617.15 & 795.37 & 33716 \\
GI-7 & 1654.05 & 809.97 & 35435 \\
GI-8, dip & 1691.10 & 818.13 & 36901 \\
GI-8 & 1716.10 & 825.66 & 38125 \\
GS-9, plateau & 1743.55 & 833.81 & 39372 \\
GI-9 & 1759.20 & 837.90 & 40121 \\
GI-10 & 1780.30 & 845.97 & 41467 \\
GI-11 & 1807.95 & 855.28 & 43351 \\
& & 861.20 & 44486 \\
GI-12 & 1863.05 & 870.43 & 46859 \\
GI-13 & 1898.30 & 882.41 & 49276 \\
\hline
\end{tabular}

\section{A2 Gas age scales}

For the NGRIP gas records $\left(\delta \mathrm{D}-\mathrm{CH}_{4}, \delta^{18} \mathrm{O}_{\text {atm }}\right)$, we use the gas age scale from Kindler et al. (2014), initially constructed on the NGRIP ss09sea06m timescale (NGRIP members, 2004; Wolff et al., 2010), and we transfer it to the GICC05 chronology. We use the NEEM gas age scale from Guillevic et al. (2013) for GS-8 to GS-12, compatible with the later release from Rasmussen et al. (2013), and the one from Rasmussen et al. (2013) for GI-12 to GI-14. The NGRIP and NEEM gas age scale covering GS-9 are well constrained (ice-gas synchronisation uncertainty less than 100 years for

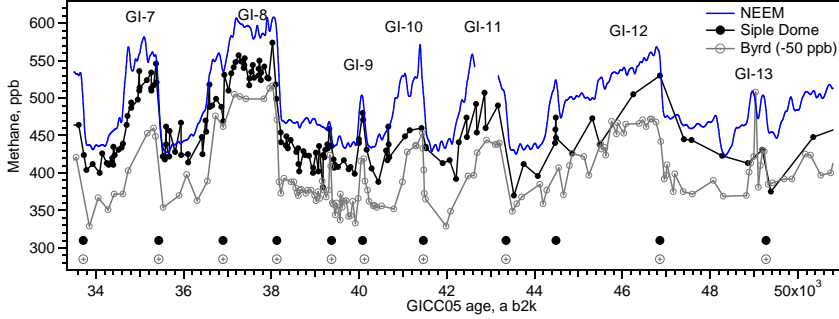

Figure A1. Construction of a gas age scale for the Byrd and Siple Dome ice cores, Antarctica. Blue line: NEEM methane data (Chappellaz et al., 2013) on the NEEM GICC05 gas age scale (Guillevic et al., 2013; Rasmussen et al., 2013). Black line and dots: Siple Dome $\mathrm{CH}_{4}$ data (Brook et al., 2005; Ahn et al., 2012) after syn-


2012) minus a $50 \mathrm{ppb}$ offset for better clearness, after synchronisation. At the bottom of the figure are indicated the position of the match points listed in Table A1: black circles for NEEM-Siple Dome match points and open grey circles for NEEM-Byrd.

NEEM, less than 160 years for NGRIP) thanks to numerous measured $\delta^{15} \mathrm{~N}$ data (Kindler et al., 2014; Guillevic et al., 2013; Rasmussen et al., 2013).

To synchronise the Byrd gas records to the NEEM ice core, we use a traditional approach by matching methane records from both ice cores (Blunier et al., 1998). We first use the high-resolution NEEM methane record on its GICC05 gas age scale (Guillevic et al., 2013). We then match the Byrd methane record (Ahn et al., 2012) to the NEEM methane record, using the mid-slope of each GI onset as match points (Fig. A1 and Table A1). We perform a linear interpolation in between the match points. We then apply the obtain depthgas age scale for Byrd to the Byrd $\mathrm{CO}_{2}$ record.

The same method is applied to the Siple Dome methane record in order to place the Siple Dome $\delta^{18} \mathrm{O}_{\text {atm }}$ record (Severinghaus et al., 2009) on the GICC05 timescale, to compare with the NEEM and NGRIP $\delta^{18} \mathrm{O}_{\text {atm }}$ record (Fig. A1 and Table A1). 
Appendix B: Timing and duration of the phases

identified during GS-9 according

to the GICC05 timescale

The results are presented in Table B1.

Table B1. Timing and duration of the phases identified during GS-9 in ice core proxies, on the GICC05 timescale. Column 2: onsets of GI and GS are given according to Rasmussen et al. (2014). Column 3: maximum counting error (MCE), reflecting the number of uncertain annual layers compared to year 2000 AD (Rasmussen et al., 2006, and Appendix A1). Column 5: MCE of the phase duration, calculated as the MCE difference between start and end of each phase. Column 6: total duration uncertainty for each phase: MCE of the phase duration, synchronisation uncertainty of the NEEM ice core to the NGRIP GICC05 timescale ( 20 a, Rasmussen et al., 2013) and data resolution $( \pm 35$ a in average).

\begin{tabular}{|c|c|c|c|c|c|}
\hline & \multicolumn{2}{|c|}{ Start time } & \multicolumn{3}{|c|}{ Duration } \\
\hline & $\mathrm{a} b 2 \mathrm{k}$ & MCE, a & $\mathrm{a}$ & MCE, a & $\begin{array}{c}\text { uncertainty } \\
(2 \sigma), \mathrm{a}\end{array}$ \\
\hline \multicolumn{6}{|c|}{ GS-13 } \\
\hline Phase 1 & 48340 & 1988 & 140 & 7 & 40 \\
\hline Phases 2 \& 3 & 48200 & 1981 & 1340 & 69 & 80 \\
\hline GI-12 & 46860 & 1912 & & & \\
\hline \multicolumn{6}{|c|}{ GS-9 } \\
\hline Phase 1 & 39900 & 1569 & 550 & 51 & 60 \\
\hline Phase 2 & 39350 & 1518 & 740 & 47 & 60 \\
\hline Phase 3 & 38610 & 1471 & 390 & 22 & 50 \\
\hline GI-8 & 38220 & 1449 & & & \\
\hline
\end{tabular}




\section{The Supplement related to this article is available online at doi:10.5194/cp-10-2115-2014-supplement.}

Acknowledgements. We thank S. O. Rasmussen and M. Bock for fruitful discussions and P. Kindler for valuable insights and support. W. Austin kindly provided the data of marine core MD95-2006 and S. Zaragosi the magnetic susceptibility data of core MD04-2845. NEEM is directed and organised by the Centre for Ice and Climate at the Niels Bohr Institute and US NSF, Office of Polar Programs. It is supported by funding agencies and institutions in 14 countries: Belgium (FNRS-CFB and FWO), Canada (GSC), China (CAS), Denmark (FIST), France (IPEV, CNRS/INSU, CEA and ANR), Germany (AWI), Iceland (RannIs), Japan (NIPR), Korea (KOPRI), the Netherlands (NWO/ALW), Sweden (VR), Switzerland (SNF), UK (NERC) and the USA (US NSF, Office of Polar Programs). LSCE analytical work has been funded by the ANR VMC NEEM project. M. Guillevic thanks the University of Copenhagen, Denmark, and the Commissariat à l'Energie Atomique Saclay, France, for funding. The publication of this article is funded by the "Fondation de France Ars Cuttoli".

Edited by: L. Skinner

\section{References}

Ahn, J. and Brook, E. J.: Atmospheric $\mathrm{CO}_{2}$ and climate on millennial time scales during the last glacial period, Science, 322, 83-85, 2008.

Ahn, J., Brook, E., Schmittner, A., and Kreutz, K.: Abrupt change in atmospheric $\mathrm{CO}_{2}$ during the last ice age, Geophys. Res. Lett., 39, L18771, doi:10.1029/2012GL053018, 2012.

Alvarez-Solas, J. and Ramstein, G.: On the triggering mechanism of Heinrich events, P. Natl. Acad. Sci. USA, 108, E1359-E1360, 2011.

Alvarez-Solas, J., Charbit, S., Ritz, C., Paillard, D., Ramstein, G., and Dumas, C.: Links between ocean temperature and iceberg discharge during Heinrich events, Nat. Geosci., 3, 122-126, 2010.

Andersen, K. K., Svensson, A., Johnsen, S. J., Rasmussen, S. O., Bigler, M., Röthlisberger, R., Ruth, U., Siggaard-Andersen, M.-L., Steffensen, J. P., Dahl-Jensen, D., Vinther, B. M., and Clausen, H. B.: The Greenland Ice Core Chronology 2005, 15$42 \mathrm{ka}$. Part 1: constructing the time scale, Quaternary Sci. Rev., 25, 3246-3257, 2006.

Anderson, R. F., Ali, S., Bradtmiller, L. I., Nielsen, S. H. H., Fleisher, M. Q., Anderson, B. E., and Burckle, L. H.: Winddriven upwelling in the Southern Ocean and the deglacial rise in atmospheric $\mathrm{CO}_{2}$, Science, 323, 1443-1448, 2009.

Auffret, G., Zaragosi, S., Dennielou, B., Cortijo, E., Rooij, D. V., Grousset, F., Pujol, C., Eynaud, F., and Siegert, M.: Terrigenous fluxes at the Celtic margin during the last glacial cycle, Mar. Geol., 188, 79-108, 2002.

Austin, W. E. and Hibbert, F. D.: Tracing time in the ocean: a brief review of chronological constraints (60-8 kyr) on North Atlantic marine event-based stratigraphies, Quaternary Sci. Rev., 36, 2837, 2012.
Austin, W. E. N., Wilson, L. J., and Hunt, J. B.: The age and chronostratigraphical significance of North Atlantic Ash zone II, J. Quaternary Sci., 19, 137-146, 2004.

Barkan, E. and Luz, B.: High precision measurements of ${ }^{17} \mathrm{O} /{ }^{16} \mathrm{O}$ and ${ }^{18} \mathrm{O} /{ }^{16} \mathrm{O}$ ratios in $\mathrm{H}_{2} \mathrm{O}$, Rapid Commun. Mass Spectrom., 19, 3737-3742, 2005.

Barker, S., Diz, P., Vautravers, M. J., Pike, J., Knorr, G., Hall, I. R., and Broecker, W. S.: Interhemispheric Atlantic seesaw response during the last deglaciation, Nature, 457, 1097-1102, 2009.

Baumgartner, M., Schilt, A., Eicher, O., Schmitt, J., Schwander, J., Spahni, R., Fischer, H., and Stocker, T. F.: High-resolution interpolar difference of atmospheric methane around the Last Glacial Maximum, Biogeosciences, 9, 3961-3977, doi:10.5194/bg-93961-2012, 2012.

Bazin, L., Landais, A., Lemieux-Dudon, B., Toyé Mahamadou Kele, H., Veres, D., Parrenin, F., Martinerie, P., Ritz, C., Capron, E., Lipenkov, V., Loutre, M.-F., Raynaud, D., Vinther, B., Svensson, A., Rasmussen, S. O., Severi, M., Blunier, T., Leuenberger, M., Fischer, H., Masson-Delmotte, V., Chappellaz, J., and Wolff, E.: An optimized multi-proxy, multi-site Antarctic ice and gas orbital chronology (AICC2012): 120-800 ka, Clim. Past, 9, 1715-1731, doi:10.5194/cpd-8-59632012, 2013.

Bender, M., Sowers, T., Dickinson, M., Orchado, J., Grootes, P., Mayewski, P., and Meese, D.: Climate correlations between Greenland and Antarctica during the past 100000 years, Nature, 372, 663-666, 1994a.

Bender, M., Sowers, T., and Labeyrie, L.: The Dole effect and its variations during the last 130000 years as measured in the Vostok ice core, Global Biogeochem. Cy., 8, 363-376, 1994b.

Bereiter, B., Lüthi, D., Siegrist, M., Schüpbach, S., Stocker, T. F., and Fischer, $\mathrm{H}$.: Mode change of millennial $\mathrm{CO}_{2}$ variability during the last glacial cycle associated with a bipolar marine carbon seesaw, P. Natl. Acad. Sci. USA, 109, 9755-9760, 2012.

Björck, S., Walker, M. J., Cwynar, L. C., Johnsen, S., Knudsen, K.L., Lowe, J. J., Wohlfarth, B., and Members, I.: An event stratigraphy for the Last Termination in the North Atlantic region based on the Greenland ice-core record: A proposal by the INTIMATE group, J. Quaternary Sci., 13, 283-292, 1998.

Blaauw, M., Wohlfarth, B., Christen, J. A., Ampel, L., Veres, D., Hughen, K. A., Preusser, F., and Svensson, A.: Were last glacial climate events simultaneous between Greenland and France? A quantitative comparison using non-tuned chronologies, J. Quaternary Sci., 25, 387-394, 2010.

Blunier, T., Chappellaz, J., Schwander, J., Dällenbach, A., Stauffer, B., Stocker, T., Raynaud, D., Jouzel, J., Clausen, H., Hammer, C., and Johnsen, S.: Asynchrony of Antarctic and Greenland climate change during the last glacial period, Nature, 394, 739-743, 1998.

Boch, R., Cheng, H., Spötl, C., Edwards, R. L., Wang, X., and Häuselmann, P.: NALPS: a precisely dated European climate record 120-60 ka, Clim. Past, 7, 1247-1259, 2011, http://www.clim-past.net/7/1247/2011/.

Bock, J., Martinerie, P., Witrant, E., and Chappellaz, J.: Atmospheric impacts and ice core imprints of a methane pulse from clathrates, Earth Planet. Sc. Lett., 349/350, 98-108, 2012.

Bock, M., Schmitt, J., Möller, L., Spahni, R., Blunier, T., and Fischer, $\mathrm{H}$.: Hydrogen isotopes preclude marine hydrate $\mathrm{CH}_{4}$ emis- 
sions at the onset of Dansgaard-Oeschger events, Science, 328, 1686-1689, 2010.

Bond, G., Heinrich, H., Broecker, W., Labeyrie, L., McManus, J., Andrews, J., Huon, S., Jantschik, R., Clasen, S., Simet, C., Tedesco, K., Klas, M., Bonani, G., and Ivy, S.: Evidence for massive discharges of icebergs into the North Atlantic ocean during the last glacial period, Nature, 360, 245-249, 1992.

Bond, G., Broecher, W., Johnsen, S. J., MacManus, J., Laberie, L., Jouzel, J., and Bonani, G.: Correlations between climate records from North Atlantic sediments and Greenland ice, Nature, 365, 143-147, 1993.

Bonne, J.-L., Masson-Delmotte, V., Cattani, O., Delmotte, M., Risi, C., Sodemann, H., and Steen-Larsen, H. C.: The isotopic composition of water vapour and precipitation in Ivittuut, southern Greenland, Atmos. Chem. Phys., 14, 4419-4439, 2014, http://www.atmos-chem-phys.net/14/4419/2014/.

Bozbiyik, A., Steinacher, M., Joos, F., Stocker, T. F., and Menviel, L.: Fingerprints of changes in the terrestrial carbon cycle in response to large reorganizations in ocean circulation, Clim. Past, 7, 319-338, doi:10.5194/cp-7-319-2011, 2011.

Brendryen, J., Haflidason, H., and Sejrup, H. P.: Non-synchronous deposition of North Atlantic Ash Zone II in Greenland ice cores, and North Atlantic and Norwegian Sea sediments: an example of complex glacial-stage tephra transport, J. Quaternary Sci., 26, 739-745, 2011.

Brook, E. J., White, J. W., Schilla, A. S., Bender, M. L., Barnett, B., Severinghaus, J. P., Taylor, K. C., Alley, R. B., and Steig, E. J.: Timing of millennial-scale climate change at Siple Dome, West Antarctica, during the last glacial period, Quaternary Sci. Rev., 24, 1333-1343, 2005.

Capron, E., Landais, A., Chappellaz, J., Schilt, A., Buiron, D., Dahl-Jensen, D., Johnsen, S. J., Jouzel, J., Lemieux-Dudon, B., Loulergue, L., Leuenberger, M., Masson-Delmotte, V., Meyer, H., Oerter, H., and Stenni, B.: Millennial and sub-millennial scale climatic variations recorded in polar ice cores over the last glacial period, Clim. Past, 6, 345-365, doi:10.5194/cp-6-3452010, 2010.

Chappellaz, J., Blunier, T., Raynaud, D., Barnola, J., Schwander, J., and Stauffer, B.: Synchronous changes in atmospheric $\mathrm{CH}_{4}$ and Greenland climate between 40 and 8 kyr BP, Nature, 366, 443445, 1993.

Chappellaz, J., Stowasser, C., Blunier, T., Baslev-Clausen, D., Brook, E. J., Dallmayr, R., Faïn, X., Lee, J. E., Mitchell, L. E., Pascual, O., Romanini, D., Rosen, J., and Schüpbach, S.: Highresolution glacial and deglacial record of atmospheric methane by continuous-flow and laser spectrometer analysis along the NEEM ice core, Clim. Past, 9, 2579-2593, doi:10.5194/cp-92579-2013, 2013.

Chiang, J. C. H., Cheng, W., and Bitz, C. M.: Fast teleconnections to the tropical Atlantic sector from Atlantic thermohaline adjustment, Geophys. Res. Lett., 35, L07704, doi:10.1029/2008GL033292, 2008.

Clement, A. C. and Peterson, L. C.: Mechanisms of abrupt climate change of the last glacial period, Rev. Geophys., 46, RG4002, doi:10.1029/2006RG000204, 2008.

Cortijo, E., Duplessy, J.-C., Labeyrie, L., Duprat, J., and Paillard, D.: Heinrich events: hydrological impact, CR Geosci., 337, 897907, 2005
Craig, H., Horibe, Y., and Sowers, T.: Gravitational separation of gases and isotopes in polar ice caps, Science, 242, 1675-1678, 1988.

Cvijanovic, I. and Chiang, J.: Global energy budget changes to high latitude North Atlantic cooling and the tropical ITCZ response, Climate Dyn., 40, 1435-1452, 2013.

Dahl-Jensen, D. and NEEM community members: Eemian interglacial reconstructed from a Greenland folded ice core, Nature, 493, 489-494, 2013.

Daniau, A.-L., Sánchez Goñi, M. F., and Duprat, J.: Last glacial fire regime variability in western France inferred from microcharcoal preserved in core MD04-2845, Bay of Biscay, Quaternary Res., 71, 385-396, 2009.

Dansgaard, W.: Stable isotopes in precipitation, Tellus, 16, 436468, 1964.

Davies, S. M., Abbott, P. M., Meara, R. H., Pearce, N. J., Austin, W. E., Chapman, M. R., Svensson, A., Bigler, M., Rasmussen, T. L., Rasmussen, S. O., and Farmer, E. J.: A North Atlantic tephrostratigraphical framework for 130 60 ka b2k: new tephra discoveries, marine-based correlations, and future challenges, Quaternary Sci. Rev., in press, doi:10.1016/j.quascirev.2014.03.024, 2014.

de Abreu, L., Shackleton, N. J., Schönfeld, J., Hall, M., and Chapman, M.: Millennial-scale oceanic climate variability off the Western Iberian margin during the last two glacial periods, Mar. Geol., 196, 1-20, 2003.

Dickson, A. J., Austin, W. E. N., Hall, I. R., Maslin, M. A., and Kucera, M.: Centennial-scale evolution of DansgaardOeschger events in the northeast Atlantic Ocean between 39.5 and 56.5 ka B.P., Paleoceanography, 23, PA3206, doi:10.1029/2008PA001595, 2008.

Dokken, T. M., Nisancioglu, K. H., Li, C., Battisti, D. S., and Kissel, C.: Dansgaard-Oeschger cycles: Interactions between ocean and sea ice intrinsic to the Nordic seas, Paleoceanography, 28, 1-12, 2013.

EPICA community members: One-to-one coupling of glacial climate variability in Greenland and Antarctica, Nature, 444, 195198, 2006.

Eynaud, F., Turon, J., Matthiessen, J., Kissel, C., Peypouquet, J., de Vernal, A., and Henry, M.: Norwegian sea-surface palaeoenvironments of marine oxygen-isotope stage 3: the paradoxical response of dinoflagellate cysts, J. Quaternary Sci., 17, 349-359, 2002.

Eynaud, F., de Abreu, L., Voelker, A., Schönfeld, J., Salgueiro, E., Turon, J.-L., Penaud, A., Toucanne, S., Naughton, F., Sánchez Goñi, M. F., Malaizé, B., and Cacho, I.: Position of the Polar Front along the western Iberian margin during key cold episodes of the last $45 \mathrm{ka}$, Geochem. Geophy. Geosy., 10, Q07U05, doi:10.1029/2009GC002398, 2009.

Eynaud, F., Malaizé, B., Zaragosi, S., de Vernal, A., Scourse, J., Pujol, C., Cortijo, E., Grousset, F. E., Penaud, A., Toucanne, S., Turon, J.-L., and Auffret, G.: New constraints on European glacial freshwater releases to the North Atlantic Ocean, Geophys. Res. Lett., 39, L15601, doi:10.1029/2012GL052100, 2012.

Flückiger, J., Knutti, R., and White, J. W. C.: Oceanic processes as potential trigger and amplifying mechanisms for Heinrich events, Paleoceanography, 21, PA2014, doi:10.1029/2005PA001204, 2006. 
Genty, D., Combourieu-Nebout, N., Peyron, O., Blamart, D., Wainer, K., Mansuri, F., Ghaleb, B., Isabello, L., Dormoy, I., von Grafenstein, U., Bonelli, S., Landais, A., and Brauer, A.: Isotopic characterization of rapid climatic events during OIS3 and OIS4 in Villars Cave stalagmites (SW-France) and correlation with Atlantic and Mediterranean pollen records, Quaternary Sci. Rev., 29, 2799-2820, 2010.

Grousset, F., Labeyrie, L., Sinko, J., Cremer, M., Bond, G., Duprat, J., Cortijo, E., and Huon, S.: Patterns of ice-rafted detritus in the glacial North Atlantic (40-55N), Paleoceanography, 8, 175-192, 1993.

Grousset, F., Pujol, C., Labeyrie, L., Auffret, G., and Boelaert, A.: Were the North Atlantic Heinrich events triggered by the behavior of the European ice sheets?, Geology, 28, 123-126, doi:10.1130/0091-7613(2000)28<123:WTNAHE>2.0.CO;2, 2000.

Guillevic, M., Bazin, L., Landais, A., Kindler, P., Orsi, A., MassonDelmotte, V., Blunier, T., Buchardt, S. L., Capron, E., Leuenberger, M., Martinerie, P., Prié, F., and Vinther, B. M.: Spatial gradients of temperature, accumulation and $\delta^{18} \mathrm{O}$-ice in Greenland over a series of Dansgaard-Oeschger events, Clim. Past, 9, 1029-1051, doi:10.5194/cp-9-1029-2013, 2013.

Gwiazda, R., Hemming, S., and Broecker, W.: Provenance of icebergs during Heinrich Event 3 and the contrast to their sources during other Heinrich episodes, Paleoceanography, 11, 371-378, doi:10.1029/96PA01022, 1996.

Heinrich, H.: Origin and consequences of cyclic ice rafting in the Northeast Atlantic Ocean during the past 130000 years, Quaternary Res., 29, 142-152, 1988.

Hemming, S., Broecker, W., Sharp, W., Bond, G., Gwiazda, R., McManus, J., Klas, M., and Hajdas, I.: Provenance of the Heinrich layers in core V28-82, northeastern Atlantic, ${ }^{40} \mathrm{Ar}-{ }^{39} \mathrm{Ar}$ ages of ice-rafted hornblende, $\mathrm{Pb}$ isotopes in feldspar grains, and $\mathrm{Nd}-\mathrm{Sr}$ $\mathrm{Pb}$ isotopes in the fine sediment fraction, Earth Planet. Sc. Lett., 164, 317-333, 1998.

Hemming, S. R.: Heinrich events: massive Late Pleistocene detritus layers of the North Atlantic and their global climate imprint, Rev. Geophys., 42, RG1005, doi:10.1029/2003RG000128, 2004.

Hoffmann, G., Cuntz, M., Weber, C., Ciais, P., Friedlingstein, P., Heimann, M., Jouzel, J., Kaduk, J., Maier-Reimer, E., Seibt, U., and Six, K.: A model of the Earth's Dole effect, Global Biogeochem. Cy., 18, GB1008, doi:10.1029/2003GB002059, 2004.

Hopcroft, P. O., Valdes, P. J., and Beerling, D. J.: Simulating idealized Dansgaard-Oeschger events and their potential impacts on the global methane cycle, Quaternary Sci. Rev., 30, 3258-3268, 2011.

Huber, C., Leuenberger, M., Spahni, R., Flückiger, J., Schwander, J., Stocker, T. F., Johnsen, S. J., Landais, A., and Jouzel, J.: Isotope calibrated Greenland temperature record over Marine Isotope Stage 3 and its relation to $\mathrm{CH}_{4}$, Earth Planet. Sc. Lett., 243, 504-519, 2006.

Itambi, A., von Dobeneck, T., Mulitza, S., Bickert, T., and Heslop, D.: Millennial-scale northwest African droughts related to Heinrich events and Dansgaard-Oeschger cycles: Evidence in marine sediments from offshore Senegal, Paleoceanography, 24, PA1205, doi:10.1029/2007PA001570, 2009.

Jo, K., Woo, K. S., Yi, S., Yang, D. Y., Lim, H. S., Wang, Y., Cheng, H., and Edwards, R. L.: Mid-latitude interhemispheric hydro- logic seesaw over the past 550000 years, Nature, 508, 378-382, doi:10.1038/nature13076, 2014.

Jonkers, L., Moros, M., Prins, M. A., Dokken, T., Dahl, C. A., Dijkstra, N., Perner, K., and Brummer, G.-J. A.: A reconstruction of sea surface warming in the northern North Atlantic during MIS 3 ice-rafting events, Quaternary Sci. Rev., 29, 1791-1800, 2010.

Jouzel, J., Stiévenard, N., Johnsen, S., Landais, A., MassonDelmotte, V., Sveinbjörnsdóttir, A., Vimeux, F., von Grafenstein, U., and White, J.: The GRIP deuterium-excess record, Quaternary Sci. Rev., 26, 1-17, 2007.

Jullien, E., Grousset, F. E., Hemming, S. R., Peck, V. L., Hall, I. R., Jeantet, C., and Billy, I.: Contrasting conditions preceding MIS3 and MIS2 Heinrich events, Global Planet. Change, 54, 225-238, 2006.

Jullien, E., Grousset, F., Malaizé, B., Duprat, J., Sánchez Goñi, M. F., Eynaud, F., Charlier, K., Schneider, R., Bory, A., Bout, V., and Flores, J. A.: Low-latitude dusty events vs. high-latitude icy Heinrich events, Quaternary Res., 68, 279-386, 2007.

Kageyama, M., Merkel, U., Otto-Bliesner, B., Prange, M., AbeOuchi, A., Lohmann, G., Ohgaito, R., Roche, D. M., Singarayer, J., Swingedouw, D., and Zhang, X.: Climatic impacts of fresh water hosing under Last Glacial Maximum conditions: a multimodel study, Clim. Past, 9, 935-953, doi:10.5194/cp-9-9352013, 2013.

Kanner, L. C., Burns, S. J., Cheng, H., and Edwards, R. L.: Highlatitude forcing of the South American summer monsoon during the Last Glacial, Science, 335, 570-573, 2012.

Kindler, P., Guillevic, M., Baumgartner, M., Schwander, J., Landais, A., and Leuenberger, M.: Temperature reconstruction from 10 to 120 kyr b2k from the NGRIP ice core, Clim. Past, 10, 887-902, doi:10.5194/cp-10-887-2014, 2014.

Landais, A., Masson-Delmotte, V., Nebout, N. C., Jouzel, J., Blunier, T., Leuenberger, M., Dahl-Jensen, D., and Johnsen, S.: Millenial scale variations of the isotopic composition of atmospheric oxygen over Marine Isotopic Stage 4, Earth Planet. Sc. Lett., 258, 101-113, 2007.

Landais, A., Dreyfus, G., Capron, E., Masson-Delmotte, V., Sánchez Goñi, M. F., Desprat, S., Hoffmann, G., Jouzel, J., Leuenberger, M., and Johnsen, S.: What drives the millennial and orbital variations of $\delta^{18} O_{a t m}$ ?, Quaternary Sci. Rev., 29, 235246, 2010.

Landais, A., Ekaykin, A., Barkan, E., Winkler, R., and Luz, B.: Seasonal variations of ${ }^{17} \mathrm{O}$-excess and d-excess in snow precipitation at the Vostok station (East Antarctica), J. Glaciol., 58, 210, doi:10.3189/2012JoG11J237, 2012a.

Landais, A., Steen-Larsen, H., Guillevic, M., Masson-Delmotte, V., Vinther, B., and Winkler, R.: Triple isotopic composition of oxygen in surface snow and water vapor at NEEM (Greenland), Geochim. Cosmochim. Ac., 77, 304-316, 2012b.

Levine, J. G., Wolff, E. W., Hopcroft, P. O., and Valdes, P. J.: Controls on the tropospheric oxidizing capacity during an idealized Dansgaard-Oeschger event, and their implications for the rapid rises in atmospheric methane during the last glacial period, Geophys. Res. Lett., 39, doi:10.1029/2012GL051866, 2012.

Lewis, S., LeGrande, A. N., Kelley, M., and Schmidt, G. A.: Water vapour source impacts on oxygen isotope variability in tropical precipitation during Heinrich events, Clim. Past, 6, 325-343, doi:10.5194/cp-6-325-2010, 2010. 
Li, C., Battisti, D., and Bitz, C.: Can North Atlantic sea ice anomalies account for Dansgaard-Oeschger climate signals?, J. Climate, 23, 5457-5475, 2010.

Luz, B. and Barkan, E.: The isotopic ratios ${ }^{17} \mathrm{O} /{ }^{16} \mathrm{O}$ and ${ }^{18} \mathrm{O} /{ }^{16} \mathrm{O}$ in molecular oxygen and their significance in biogeochemistry, Geochim. Cosmochim. Ac., 69, 1099-1110, 2005.

Luz, B., Barkan, E., Yam, R., and Shemesh, A.: Fractionation of oxygen and hydrogen isotopes in evaporating water, Geochim. Cosmochim. Ac., 73, 6697-6703, 2009.

Majoube, M.: Fractionnement en oxygène 18 et en deutérium entre l'eau et sa vapeur, J. Clim. Phys., 68, 1423-1436, 1971.

Marcott, S. A., Clark, P. U., Padman, L., Klinkhammer, G. P., Springer, S. R., Liu, Z., Otto-Bliesner, B. L., Carlson, A. E., Ungerer, A., Padman, J., He, F., Cheng, J., and Schmittner, A.: Iceshelf collapse from subsurface warming as a trigger for Heinrich events, P. Natl. Acad. Sci. USA, 108, 13415-13419, 2011.

Masson-Delmotte, V., Jouzel, J., Landais, A., Stiévenard, M., Johnsen, S. J., White, J. W. C., Werner, M., Sveinbjörnsdóttir, A., and Fuhrer, K.: GRIP deuterium excess reveals rapid and orbitalscale changes in Greenland moisture origin, Science, 309, 118 $121,2005$.

Menviel, L., England, M., Meissner, K., Mouchet, A., and Yu, J.: Atlantic-Pacific seesaw and its role in outgassing $\mathrm{CO}_{2}$ during Heinrich events, Paleoceanography, 29, 1-13, 2014.

Möller, L., Sowers, T., Bock, M., Spahni, R., Behrens, M., Schmitt, J., Miller, H., and Fischer, H.: Independent variations of $\mathrm{CH}_{4}$ emissions and isotopic composition over the past 160000 years, Nat. Geosci., 6, 885-890, 2013.

Mosblech, N. A., Bush, M. B., Gosling, W. D., Hodell, D., Thomas, L., van Calsteren, P., Correa-Metrio, A., Valencia, B. G., Curtis, J., and van Woesik, R.: North Atlantic forcing of Amazonian precipitation during the last ice age, Nat. Geosci., 5, 817-820, 2012

Mulitza, S., Prange, M., Stuut, J.-B., Zabel, M., von Dobeneck, T., Itambi, A. C., Nizou, J., Schulz, M., and Wefer, G.: Sahel megadroughts triggered by glacial slowdowns of Atlantic meridional overturning, Paleoceanography, 23, PA4206, doi:10.1029/2008PA001637, 2008.

Naughton, F., Sánchez Goñi, M. F., Kageyama, M., Bard, E., Duprat, J., Cortijo, E., Desprat, S., Malaizé, B., Joly, C., Rostek, F., and Turon, J.-L.: Wet to dry climatic trend in north-western Iberia within Heinrich events, Earth Planet. Sc. Lett., 284, 329342, 2009

NGRIP members: High-resolution record of Northern Hemisphere climate extending into the last interglacial period, Nature, 431, 147-151, 2004.

Pausata, F. S. R., Battisti, D. S., Nisancioglu, K. H., and Bitz, C. M.: Chinese stalagmite $\delta^{18} \mathrm{O}$ controlled by changes in the Indian monsoon during a simulated Heinrich event, Nat. Geosci., 4, 474-480, 2011.

Peters, C., Walden, J., and Austin, W. E. N.: Magnetic signature of European margin sediments: Provenance of ice-rafted debris and the climatic response of the British ice sheet during Marine Isotope Stages 2 and 3, J. Geophys. Res.-Earth, 113, F03007, doi:10.1029/2007JF000836, 2008.

Petersen, S. V., Schrag, D. P., and Clark, P. U.: A new mechanism for Dansgaard-Oeschger cycles, Paleoceanography, 28, 24-30, 2013.
Peterson, L. C., Haug, G. H., Hughen, K. A., and Röhl, U.: Rapid changes in the hydrologic cycle of the tropical Atlantic during the Last Glacial, Science, 290, 1947-1951, 2000.

Rashid, H., Hesse, R., and Piper, D.: Evidence for an additional Heinrich event between H5 and H6 in the Labrador Sea, Paleoceanography, 18, 1077, doi:10.1029/2003PA000913, 2003.

Rasmussen, S., Bigler, M., Blockley, S., Blunier, T., Buchardt, S. L., Clausen, H. B., Cvijanovic, I., Dahl-Jensen, D., Johnsen, S. J., Fischer, H., Gkinis, V., Guillevic, M., Hoek, W., Lowe, J. J., Pedro, J., Popp, T., Seierstad, I. E., Steffensen, J., Svensson, A. M., Vallelonga, P., Vinther, B. M., Walker, M. J., Wheatley, J., and Winstrup, M.: A stratigraphic framework for robust naming and correlation of past abrupt climatic changes during the last glacial period based on three synchronized Greenland ice core records, Quaternary Sci. Rev., in press, 2014.

Rasmussen, S. O., Andersen, K. K., Svensson, A. M., Steffensen, J. P., Vinther, B. M., Clausen, H. B., Siggaard-Andersen, M.L., Johnsen, S. J., Larsen, L. B., Dahl-Jensen, D., Bigler, M., Röthlisberger, R., Fischer, H., Goto-Azuma, K., Hansson, M. E., and Ruth, U.: A new Greenland ice core chronology for the last glacial termination, J. Geophys. Res., 111, D06102, doi:10.1029/2005JD006079, 2006.

Rasmussen, S. O., Abbott, P. M., Blunier, T., Bourne, A. J., Brook, E., Buchardt, S. L., Buizert, C., Chappellaz, J., Clausen, H. B., Cook, E., Dahl-Jensen, D., Davies, S. M., Guillevic, M., Kipfstuhl, S., Laepple, T., Seierstad, I. K., Severinghaus, J. P., Steffensen, J. P., Stowasser, C., Svensson, A., Vallelonga, P., Vinther, B. M., Wilhelms, F., and Winstrup, M.: A first chronology for the North Greenland Eemian Ice Drilling (NEEM) ice core, Clim. Past, 9, 2713-2730, doi:10.5194/cp-9-2713-2013, 2013.

Rasmussen, T., Oppo, D., Thomsen, E., and Lehman, S.: Deep sea records from the southeast Labrador Sea: Ocean circulation changes and ice-rafting events during the last 160000 years, $\mathrm{Pa}$ leoceanography, 18, 1018, doi:10.1029/2001PA000736, 2003.

Rasmussen, T. L. and Thomsen, E.: The role of the North Atlantic Drift in the millennial timescale glacial climate fluctuations, Palaeogeogr. Palaeocl., 210, 101-116, 2004.

Reimer, P. J., Bard, E., Bayliss, A., Beck, J. W., Blackwell, P. G., Ramsey, C. B., Buck, C. E., Cheng, H., Edwards, R. L., Friedrich, M., Grootes, P. M., Guilderson, T. P., Haflidason, H., Hajdas, I., Hatté, C., Heaton, T. J., Hoffmann, D. L., Hogg, A. G., Hughen, K. A., Kaiser, K. F., Kromer, B., Manning, S. W., Niu, M., Reimer, R. W., Richards, D. A., Scott, E. M., Southon, J. R., Staff, R. A., Turney, C. S. M., and van der Plicht, J.: IntCal13 and Marine13 radiocarbon age calibration curves $0-50,000$ years cal PB, Radiocarbon, 55, 1869-1887, 2013.

Risi, C., Landais, A., Bony, S., Jouzel, J., Masson-Delmotte, V., and Vimeux, F.: Understanding the ${ }^{17} \mathrm{O}$ excess glacial-interglacial variations in Vostok precipitation, J. Geophys. Res.-Atmos., 115, D10112, doi:10.1029/2008JD011535, 2010.

Roche, D., Paillard, D., and Cortijo, E.: Constraints on the duration and freshwater release of Heinrich event 4 through isotope modelling, Nature, 432, 379-382, 2004.

Roche, D., Wiersma, A., and Renssen, H.: A systematic study of the impact of freshwater pulses with respect to different geographical locations, Climate Dyn., 34, 997-1013, 2010.

Ruddiman, W. F.: Late Quaternary deposition of ice-rafted sand in the subpolar North Atlantic (lat 40 to $65 \mathrm{~N}$ ), Geol. Soc. Am. Bull., 88, 1813-1827, 1977. 
Sánchez Goñi, M. F. and Harrison, S.: Millennial-scale climate variability and vegetation changes during the Last Glacial: Concepts and terminology, Quaternary Sci. Rev., 29, 2823-2827, 2010.

Sánchez Goñi, M. F., Landais, A., Fletcher, W. J., Naughton, F., Desprat, S., and Duprat, J.: Contrasting impacts of DansgaardOeschger events over a western European latitudinal transect modulated by orbital parameters, Quaternary Sci. Rev., 27, 1136-1151, 2008.

Schoenemann, S. W., Schauer, A. J., and Steig, E. J.: Measurement of SLAP2 and GISP $\delta^{17} \mathrm{O}$ and proposed VSMOW-SLAP normalization for $\delta^{17} \mathrm{O}$ and ${ }^{17} \mathrm{O}_{\text {excess }}$, Rapid Commun. Mass Sp., 27, 582-590, 2013.

Schoenemann, S. W., Steig, E. J., Ding, Q., Markle, B. R., and Schauer, A. J.: Triple water-isotopologue record from WAIS Divide, Antarctica: controls on glacial-interglacial changes in 17Oexcess of precipitation, J. Geophys. Res., 119, doi:10.1002/2014JD021770, 2014.

Schwander, J.: The transformation of snow to ice and the occlusion of gases, J. Wiley and Sons Limited, New York, 1989.

Severinghaus, J., Grachev, A., and Battle, M.: Thermal fractionation of air in polar firn by seasonal temperature gradients, Geochem. Geophy. Geosy., 2,146, doi:10.1029/2000GC000146, 2001.

Severinghaus, J., Beaudette, R., Headly, M. A., Taylor, K., and Brook, E. J.: Oxygen-18 of $\mathrm{O}_{2}$ records the impact of abrupt climate change on the terrestrial biosphere, Science, 324, 14311434, 2009.

Shaffer, G., Olsen, S. M., and Bjerrum, C. J.: Ocean subsurface warming as a mechanism for coupling Dansgaard-Oeschger climate cycles and ice-rafting events, Geophys. Res. Lett., 31, L24202, doi:10.1029/2004GL020968, 2004.

Skinner, L. C. and Elderfield, H.: Rapid fluctuations in the deep North Atlantic heat budget during the last glacial period, Paleoceanography, 22, PA1205, doi:10.1029/2006PA001338, 2007.

Snoeckx, H., Grousset, F., Revel, M., and Boelaert, A.: European contribution of ice-rafted sand to Heinrich layers H3 and H4, Mar. Geol., 158, 197-208, 1999.

Sowers, T.: Late quaternary atmospheric $\mathrm{CH}_{4}$ isotope record suggests marine clathrates are stable, Science, 311, 838-840, 2006.

Stanford, J., Rohling, E., Bacon, S., Roberts, A., Grousset, F., and Bolshawa, M.: A new concept for the paleoceanographic evolution of Heinrich event 1 in the North Atlantic, Quaternary Sci. Rev., 30, 1047-1066, 2011.

Steen-Larsen, H. C., Johnsen, S. J., Masson-Delmotte, V., Stenni, B., Risi, C., Sodemann, H., Balslev-Clausen, D., Blunier, T., Dahl-Jensen, D., Ellehøj, M. D., Falourd, S., Grindsted, A., Gkinis, V., Jouzel, J., Popp, T., Sheldon, S., Simonsen, S. B., Sjolte, J., Steffensen, J. P., Sperlich, P., Sveinbjörnsdóttir, A. E., Vinther, B. M., and White, J. W. C.: Continuous monitoring of summer surface water vapor isotopic composition above the Greenland Ice Sheet, Atmos. Chem. Phys., 13, 4815-4828, doi:10.5194/acp-13-4815-2013, 2013.

Stenni, B., Masson-Delmotte, V., Johnsen, S., Jouzel, J., Longinelli, A., Monnin, E., Röthlisberger, R., and Selmo, E.: An oceanic cold reversal during the last deglaciation, Science, 293, 20742077, 2001.

Stocker, T. F. and Johnsen, S. J.: A minimum thermodynamic model for the bipolar seesaw, Paleoceanography, 18, 1087, doi:10.1029/2003PA000920, 2003.
Svensson, A., Andersen, K., Bigler, M., Clausen, H., Dahl-Jensen, D., Davies, S., Johnsen, S., Muscheler, R., Rasmussen, S., Röthlisberger, R., Steffensen, J., and Vinther, B.: The Greenland Ice Core Chronology 2005, 15-42 ka. Part 2: comparison to other records, Quaternary Sci. Rev., 25, 3258-3267, 2006.

Svensson, A., Andersen, K. K., Bigler, M., Clausen, H. B., DahlJensen, D., Davies, S. M., Johnsen, S. J., Muscheler, R., Parrenin, F., Rasmussen, S. O., Röthlisberger, R., Seierstad, I., Steffensen, J. P., and Vinther, B. M.: A 60000 year Greenland stratigraphic ice core chronology, Clim. Past, 4, 47-57, doi:10.5194/cp-4-472008, 2008.

Thouveny, N., Moreno, E., Delanghe, D., Candon, L., Lancelot, Y., and Shackleton, N.: Rock magnetic detection of distal ice-rafted debries: clue for the identification of Heinrich layers on the Portuguese margin, Earth Planet. Sci. Lett., 180, 61-75, 2000.

Toggweiler, J., Russell, J., and Carson, S.: Midlatitude westerlies, atmospheric $\mathrm{CO}_{2}$, and climate change during the ice ages, Paleoceanography, 21, PA2005, doi:10.1029/2005PA001154, 2006.

Vautravers, M. J., Shackleton, N. J., Lopez-Martinez, C., and Grimalt, J. O.: Gulf Stream variability during marine isotope stage 3, Paleoceanography, 19, PA2011, doi:10.1029/2003PA000966, 2004.

Veres, D., Bazin, L., Landais, A., Kele, H. T. M., Lemieux-Dudon, B., Parrenin, F., Martinerie, P., Blayo, E., Blunier, T., Capron, E., Chappellaz, J., Rasmussen, S. O., Severi, M., Svensson, A., Vinther, B., , and Wolff, E. W.: The Antarctic ice core chronology (AICC2012): an optimized multi-parameter and multi-site dating approach for the last 120 thousand years, Clim. Past, 9, 17331748, doi:10.5194/cp-9-1733-2013, 2013.

Vimeux, F., Masson, V., Jouzel, J., Stievenard, M., and Petit, J.: Glacial-interglacial changes in ocean surface conditions in the Southern Hemisphere, Nature, 398, 410-413, 1999.

Vinther, B. M., Clausen, H. B., Johnsen, S. J., Rasmussen, S. O., Andersen, K. K., Buchardt, S. L., Dahl-Jensen, D., Seierstad, I. K., Siggaard-Andersen, M.-L., Steffensen, J. P., and Svensson, A.: A synchronized dating of three Greenland ice cores throughout the Holocene, J. Geophys. Res., 111, D13102, doi:10.1029/2005JD006921, 2006.

Voelker, A. H., Lebreiro, S., Schönfeld, J., Cacho, I., Erlenkeuser, H., and Abrantes, F.: Mediterranean outflow strengthening during northern hemisphere coolings: A salt source for the glacial Atlantic?, Earth Planet. Sc. Lett., 245, 39-55, 2006.

Voelker, A. H. L.: Global distribution of centennial-scale records for Marine Isotope Stage (MIS) 3: a database, Quaternary Sci. Rev., 21, 1185-1212, 2002.

Völker, C. and Köhler, P.: Responses of ocean circulation and carbon cycle to changes in the position of the Southern Hemisphere westerlies at Last Glacial Maximum, Paleoceanography, 28, 726-739, 2013.

Wang, X., Auler, A. S., Edwards, R. L., Cheng, H., Ito, E., Wang, Y., Kong, X., and Solheid, M.: Millennial-scale precipitation changes in southern Brazil over the past 90000 years, Geophys. Res. Lett., 34, L23701, doi:10.1029/2007GL031149, 2007.

Wang, Y. J., Cheng, H., Edwards, R. L., An, Z. S., Wu, J. Y., Shen, C. C., and Dorale, J. A.: A high-resolution absolute-dated Late Pleistocene monsoon record from Hulu Cave, China, Science, 294, 2345-2348, 2001.

Winkler, R., Landais, A., Sodemann, H., Dümbgen, L., Prié, F., Masson-Delmotte, V., Stenni, B., and Jouzel, J.: Deglaciation 
records of ${ }^{17} \mathrm{O}$-excess in East Antarctica: reliable reconstruction of oceanic normalized relative humidity from coastal sites, Clim. Past, 8, 1-16, doi:10.5194/cp-8-1-2012, 2012.

Wolff, E. W., Chappellaz, J., Blunier, T., Rasmussen, S. O., and Svensson, A.: Millennial-scale variability during the last glacial: The ice core record, Quaternary Sci. Rev., 29, 2828-2838, 2010.
Zumaque, J., Eynaud, F., Zaragosi, S., Marret, F., Matsuzaki, K. M., Kissel, C., Roche, D. M., Malaizé, B., Michel, E., Billy, I., Richter, T., , and Palis, E.: An ocean-ice coupled response during the last glacial: a view from a marine isotopic stage 3 record south of the Faeroe Shetland Gateway, Clim. Past, 8, 1997-2017, doi:10.5194/cp-8-1997-2012, 2012. 